\title{
Rememorando a Violeta el día de su fuga: Identificaciones y reafirmaciones
}

\author{
Remembering Violeta on the day of her escape: \\ Identifications and reaffirmations
}

\author{
David Spener*
}

Resumen: Este trabajo presenta un estudio socio histórico de los homenajes rituales realizados por cantores, artistas y activistas de izquierda frente a la tumba de Violeta Parra cada 5 de febrero en Santiago de Chile. Los homenajes datan de los primeros años después de su muerte en 1967 y persistieron durante la dictadura militar, cuando adquirieron una importante carga política y han seguido sin interrupción hasta el presente día. El análisis privilegia los conceptos de memoria colectiva, trauma cultural, generación social y la importancia del canto en los movimientos sociales.

Palabras clave: Violeta Parra, movimientos sociales, memoria colectiva, trauma cultural, generación social, canto comprometido.

\begin{abstract}
This paper presents a sociohistorical study of the ritual homages carried out by singers, artists, and left-wing activists at the graveside of Violeta Parra every February 5 in Santiago, Chile. The homages date from the years immediately following her death in 1967 and persisted during the military dictatorship, when they acquired an important political dimension. They have continued without interruption to the present day. The analysis privileges the concepts of collective memory, cultural trauma, social generation, and the importance of song in social movements.
\end{abstract}

Key words: Violeta Parra, social movements, collective memory, cultural trauma, social generation, political song.

Recibido: 2 enero 2018

Aceptado: 16 febrero 2018

\footnotetext{
* Estadounidense; Director del Departamento de Sociología y Antropología de Trinity University en San Antonio, Texas EEUU. Correo electrónico: dspener@trinity.edu. El autor agradece a Trinity University por financiar la investigación que resultó en la publicación de este artículo y a Carlos Canales Ureta por corregirle los errores de gramática, ortografía y léxico en español.
} 
En este trabajo me dedico a narrar y analizar la historia de unos homenajes populares a Violeta Parra que se han realizado frente a su tumba en el Cementerio General de Santiago cada 5 de febrero, fecha en que se suicidó en 1967. Estos homenajes datan de los primeros años después de su muerte y persistieron durante toda la dictadura militar, cuando adquirieron una importante carga de disidencia política, y han seguido sin interrupción hasta el presente día. Las personas que han participado y siguen participando en los homenajes en la actualidad son de una generación que fue fuertemente marcada por sus experiencias en la resistencia a la dictadura militar. Para estas personas, la figura de Violeta Parra es simultáneamente una inspiración y un sostén en sus luchas a favor de una sociedad más justa y en contra del olvido, no solamente el olvido del dolor de la represión que muchos sufrieron a manos del régimen pinochetista sino también el de la resistencia, muchas veces heroica, de parte de los miembros de su generación que batallaron sin tregua por el retorno a la democracia y la restauración del proyecto socialista iniciado por Salvador Allende. Y aún más, Violeta representa para estas personas el rescate y la reivindicación de la cultura popular de los campesinos y obreros chilenos cuyas prácticas culturales y valores tradicionales han sido rebasados por la vorágine del capitalismo moderno, en el que "todo lo sólido se desvanece en el aire"

El trabajo está dividido en cinco apartados. En el primero, reviso algunos conceptos sociológicos y antropológicos que son relevantes para el análisis de la práctica de estos homenajes. En el segundo, me dedico a un breve repaso de los aspectos de la vida y la obra de Violeta Parra que tienen relevancia para entender cómo su figura se ha vuelto icónica para las personas que han llegado a venerarla como fuente de inspiración y sostén de sus propias vidas y luchas colectivas. En el siguiente apartado, reconstruyo, en la medida de lo posible, la historia de los homenajes populares a Violeta frente a su tumba, describiendo los varios individuos y colectivos que los han promocionado, las prácticas que han elaborado en la realización de los homenajes y sus razones por realizarlos. En el cuarto apartado, presento cómo los participantes en los homenajes se identifican social y afectivamente con Violeta y su obra, mientras en las conclusiones reviso por qué creen que sigue siendo importante homenajear a Violeta Parra en la actualidad, medio siglo después de su muerte.

\section{Marco conceptual para guiar el análisis}

Los homenajes, por definición, son rituales culturales dedicados a rememorar a algún personaje o a algún acontecimiento importante en la historia de un pueblo o, en menor escala, de un grupo social. El propósito de tales rituales es evitar o al menos posponer el olvido en la memoria colectiva, de las hazañas de uno de sus miembros o algún aspecto de su experiencia colectiva del pasado que, a juicio de las personas que los realizan, son imprescindibles para preservar su identidad y mantener su cohesión grupal (Connerton, 1989; Olick, 2008). El sociólogo Maurice Halbwachs fue el primero, en la década de los años veinte del siglo pasado, en observar que la memoria es un fenómeno eminentemente colectivo, o sea que depende no solo de las mentes de los individuos, sino que es algo producido socialmente por la interacción de los miembros de una sociedad o grupo (Halbwachs, 1992). Para él, es importante distinguir entre la historia, con la que los vivos no tienen una relación directa y experiencial, y la memoria colectiva, que representa "el 
pasado activo que conforma nuestras identidades" (Olick and Robbins 1998:111, traducción del autor). ${ }^{1}$ Ahora bien, y esto es clave para el análisis de los homenajes presentados en este trabajo, una historia puede mantener su carácter de "pasado vivo" solo si la celebran a través de repetidas ceremonias colectivas que ayudan a evitar que ella se vuelva "pasado muerto" al que los vivos solamente tengan acceso a través de las fichas históricas consignadas en los llamados "vertederos del conocimiento" (Olick and Robbins 1998:111, traducción del autor), o, peor aún, que las experiencias de un grupo en una sociedad sean completamente olvidadas por nunca haber sido grabadas debidamente por los historiadores. Las rememoraciones ritualizadas ceremonialmente, cuando son repetidas por un tiempo suficiente, se vuelven "tradiciones" arraigadas en la cultura del grupo o la sociedad en cuestión, sin importar si tales tradiciones fueron solo "inventos" de ciertos individuos o facciones del grupo para cimentar su interpretación del pasado del grupo en la conciencia colectiva de sus miembros (Hobsbawm, 1983). El primero en reconocer la significancia de los rituales en la construcción y mantenimiento de la conciencia e identidad colectivas de los grupos fue el sociólogo Emile Durkheim en su estudio pionero sobre el papel jugado por la religión en la sociedad. Aquí debemos subrayar que el mismo Durkheim reconoció que los rituales no solamente juegan este papel en el ámbito religioso, sino que también en el secular, donde sobresale el dominio cívico de las naciones modernas (Durkheim 1971; véase también Connerton, 1989 y Olick, 2008). De especial relevancia para el caso de los homenajes a Violeta Parra es cómo el uso ritual del canto y la música han sido indispensables para mantener el ánimo, la cohesión y la memoria en los movimientos sociales, un fenómeno que se ha demostrado en múltiples estudios socio históricos (véase, por ejemplo, Eyerman, 2002; Futrell, Simi y Gottschalk, 2006; Rosenthal y Flacks, 2011; y Spener, 2017). ${ }^{2}$

Otros dos conceptos sociológicos son indispensables para analizar la práctica de los homenajes a Violeta Parra frente a su tumba. El primero es el concepto de trauma cultural, que guarda una relación esencial con el segundo, el de generación social. Ambos conceptos, a su vez, también guardan una relación íntegra con el concepto de memoria colectiva discutido arriba. Alexander (2004:1) asevera que "el trauma cultural ocurre cuando los miembros de una colectividad sienten que han sido sometidos a un horrendo acontecimiento que les deja marcas indelebles en su conciencia colectiva, afectando para siempre su memoria y alterando su futura identidad de manera fundamental e irrevocable" (traducción del autor). Por otro lado, hace unos noventa años, Karl Mannheim (1972), dirigió su atención al problema de la formación y función de las generaciones en los procesos de cambio socio histórico. Concluyó que una generación se forma no simplemente en base a compartir un mismo periodo temporal de vida y/o una misma relación etaria con respecto a sus antecesores y sucesores sanguíneos, sino que también debe nacer de una experiencia en común de algún acontecimiento histórico en la juventud, muchas veces traumática, que juega un papel significativo en la formación de su conciencia y del modo de

${ }^{1}$ Los términos memoria social y memoria cultural aparecen en la literatura social científica como sinónimos de memoria colectiva. Véase Errl 2008 y Olick y Robbins 1998.

${ }^{2}$ Véase también García Méndez (2016) y Diemert (2011) para una discusión más amplia sobre música, memoria e identidad cultural. 
interpretar el mundo y orientar las acciones individuales y colectivas durante el resto de sus vidas (véase Edmunds y Turner, 2002; Nugin 2010; Olick y Robbins, 1998 Schuman y Scott, 1989). Además, otros estudios más recientes sobre cómo las generaciones se insertan en los procesos de cambio socio históricos, han encontrado que la constitución de las generaciones depende de manera indispensable de "la institucionalización de la memoria a través de rituales y narrativas colectivos" (Eyerman y Turner, 1998:93, traducción del autor; véase también Edmunds y Turner, 2002).

Como se delinea a continuación, los realizadores de los homenajes a Violeta Parra descritos en este trabajo son de una generación de artistas y activistas de izquierda cuyas vidas fueron no solo marcadas por el trauma de la derrota del proyecto socialista de la Unidad Popular, sino que también por los años de represión bajo la dictadura militar y su posterior marginación política y social después del retorno a la democracia en Chile. Esto implicó que se hayan sentido "ninguneados" en la pos-dictadura, época que ha inducido la desmovilización de las fuerzas políticas de resistencia y el auge de una sociedad neoliberal caracterizada por el individualismo, el consumismo, la entretención digital y la desigualdad económica (Arias y del Campo 2009; Moulian, 1997 y 1998). Por esta y otras razones han recurrido a la figura de Violeta Parra en busca de inspiración, sabiduría, sanación, consuelo y, sobretodo, fuerza. Sin ser necesariamente simpatizantes de la organización política que lleva el nombre, son miembros de la llamada "Generación 80" en Chile, conformada por "personas que desde distintas posiciones ideológicas y políticas en los años 80, [participaron] activamente en la lucha contra la dictadura" y que además pagaron un muy alto precio por haber luchado por el retorno a la democracia, siendo detenidos, relegados, sufriendo tortura, exilio y, además, muerte a manos de las fuerzas militares. Ahora, en el siglo XXI, ven que muchas de las cosas por las que lucharon siguen pendientes y algunos, incluyendo a la mayoría de los participantes en los homenajes a Violeta, buscan "retomar las causas que [dejaron] pendientes, valorando lo que han realizado en este período aquellos que no han dado tregua a las injusticias, especialmente la gente que ha mantenido en alto la lucha por verdad y justicia en el tema de los derechos humanos" (Movimiento Generación 80, 2007). Teniendo en cuenta estas observaciones, podemos decir que la Generación 80 cumple las características que conforman una generación política que según Longa (2017:219) "surge cuando un grupo rechaza el orden existente e intenta redirigir el curso de las políticas como su "misión generacional." En el siguiente apartado, discuto los atributos de la vida y obra de Violeta Parra que han inspirado que los miembros de la Generación 80 la celebren como un ícono en las luchas por la justicia social en Chile.

\section{Violeta Parra: aspectos relevantes de su vida y obra}

La biografía y obra de Violeta Parra seguro serán conocidas para la mayoría de los lectores de este trabajo. Aquí no pretendo aportar nuevos hechos sobre los pormenores de su vida ni analizar los productos de su creación, sino esbozar algunos aspectos de su figura que la han hecha icónica para las y los participantes en los homenajes descritos en estas páginas. Me limito aquí a resaltar algunas de sus experiencias de vida, su oficio de folclorista, su estatus como mujer, su fuerte carácter, su compromiso con la justicia social y el contenido lírico de su obra como poeta y cantautora, que han contribuido a que los miembros de la 
"Generación 80", descrita arriba, la hayan llegado a venerar con tanto afán durante ya muchos años. Dicho de otra manera, tocaré aquí, grosso modo, los aspectos de la vida y obra de Violeta que la hacen "venerable" para estos miembros de la Generación $80 .^{3}$

Para empezar, Violeta Parra nace y crece en la provincia de Nuble en el sur de Chile hacia principios de lo que el escritor uruguayo Eduardo Galeano llamó "el siglo del viento" en América Latina, un siglo marcado por transformaciones radicales -y muchas veces crueles- en los modos de vida de sus habitantes debido a la extensión y profundización de los procesos de desarrollo capitalista e imperialista en el continente (Galeano, 2002). Aunque sus padres no fueran precisamente campesinos en el sentido estricto de dedicarse a cultivar la tierra, Violeta conoce la realidad campesina y experimenta en carne propia la precariedad y la pobreza asociadas con esa clase de la que nace la cultura popular en Chile. Como a muchos chilenos, los estragos provocados por la Gran Depresión le obligan a buscar una nueva vida en Santiago, en busca de oportunidades que le fueron negadas en el campo y los pequeños pueblos del sur. En Santiago, encuentra empleo tocando guitarra y cantando en boliches cuya clientela consistía principalmente en obreros que se concentraban en los sectores populares de la ciudad para trabajar en las nacientes industrias, la construcción y los servicios manuales, todos ellos empleos muy mal remunerados. Así conoce la cruda realidad urbana del proletariado chileno y experimenta en carne propia el fuerte sexismo practicado en el chile de esa época. En este sentido, la vida de Violeta ejemplifica las experiencias de miles de chilenas y chilenos de la primera mitad del siglo $\mathrm{XX}$, quienes se vieron obligados a abandonar una vida y cultura tradicionales en el campo para probar suerte en la gran ciudad, que era poco acogedora para las multitudes sin educación formal ni recursos financieros adecuados para prosperar en el ambiente individualista y de competencia salvaje que caracterizaba la vida citadina durante la peor crisis en la historia del capitalismo (Torres Alvarado, 2004 y Verba, 2013). ${ }^{4}$

En 1934, Violeta conoce a un empleado de ferrocarriles y militante comunista, Luis Cereceda, y se casa con él en 1938. Su conflictivo matrimonio duró una década, periodo en el cual Violeta dió a luz a dos hijos, Ángel e Isabel, y participó en actividades políticas del Partido Comunista (véase Corvalán, 1997:90; Marín, 2009:133-134; Nuevo Mundo Patagonia, 2017 y Verba, 2013). Su asociación con el partido seguramente le ayudó a desarrollar una comprensión política del mundo y profundizó su compromiso con las luchas por la justicia social, un compromiso que ya había echado raíces en el suelo fértil de su propia experiencia como miembro de las clases populares, primero en el campo y luego en la ciudad. Al mismo tiempo, la joven madre se encontró dominada, restringida y explotada por su matrimonio con un comunista que predicaba la liberación del proletariado, pero esperaba que la mujer en su hogar le sirviera de manera sumisa a él y a sus hijos, renunciando así a la satisfacción de sus propios deseos y ambiciones. Fue solamente la primera de varias dolorosas relaciones amorosas que tuvo con hombres de su época,

\footnotetext{
${ }^{3}$ Las fuentes de la información sobre la biografía y obra de Violeta presentada en este apartado incluyen: Contreras Román (2016); Epple (1977); González, Ohlsen y Rolle (2009); Miranda Herrera (2014); McSherry (2017); Morales (2003); Parra (1998); Parra (2009); Pinochet Cobos (2010); Ríos (2008); Rodríguez 2015; Sáez (2012); Štambuk y Bravo (2011); Torres Alvarado (2004); y Verba (2007 y 2013 ).

${ }^{4}$ Varios libros describen este periodo de migración masiva del campo a la ciudad a mediados del siglo XX en Chile. Véase, por ejemplo, Drake (1993;87-122), Loveman (1979:258-270) y Rector (2003:138-144).
} 
ninguna con un final feliz, dejándola como madre soltera y sin sostén económico, con proyectos de vida que no cuadraban con el rol que la sociedad les había asignado a las madres. Fue, en muchos sentidos, una mujer adelantada a su tiempo, pues en su convicción y rebeldía nunca volvió a permitir, tras la ruptura de su matrimonio con Cereceda, que las normas de género y de maternidad le impidieran el desarrollo de sus proyectos de vida. Además, podemos agregar que Violeta llama mucho la atención de mujeres chilenas y latinoamericanas no solamente por ser una mujer que nunca se doblegó ante la dominación masculina, sino también por haber pagado un muy alto precio por su inconformidad con las expectativas de género de la época. A pesar de sus muchos logros como artista y los laureles recibidos, sufrió mucho como mujer por su apariencia física, su personalidad rebelde y sus amores no correspondidos. ${ }^{5}$

Para comienzos de la década de los cincuenta, Violeta se había dado cuenta de que la vorágine de la modernidad arrasaba con lo poco que quedaba de las costumbres y prácticas folclóricas de los habitantes del campo chileno. ${ }^{6}$ Animada por su hermano mayor, el poeta Nicanor, Violeta emprendió el proyecto de investigar e intentar rescatar el folclor chileno en peligro de extinción, saliendo, grabadora en mano, a buscar y grabar a las y los cantores, payadores y poetas decimistas que aún practicaban sus oficios tradicionales. Comentó su afán por el rescate del folclor diciendo que había visto que "el modernismo había matado la tradición de la música del pueblo" y que "los indios" y "los campesinos" estaban perdiendo su arte de tal manera que "la tradición es casi ya un cadáver." Solamente se consolaba por "poder pasearme entre mi alma, muy vieja y esta vida de hoy" (citada en Morales 2003:45).

En efecto, Violeta pudo rescatar del olvido a decenas de practicantes del folclor y centenares de canciones y refranes de la tradición popular chilena, presentando a muchos de los exponentes de estas tradiciones y cantando sus temas en su popular programa radial Así Canta Violeta Parra. En este sentido, Parra aprovechó las herramientas de la modernidad -las grabaciones análogas y las transmisiones radiales- para contrarrestar las fuerzas del olvido desatadas por la misma modernidad capitalista, al igual que harían sus admiradores décadas después en el siglo XXI con las tecnologías y redes sociales (Facebook, WhatsApp, Instagram, Soundcloud, etcétera) para preservar su memoria y todo lo que, a su juicio, ella representaba. Aquí, debemos recalcar que Violeta no solo rescató estas tradiciones, sino que también, las aprendió, dominó y extendió como nadie más. Así Violeta se hizo no solo una intérprete del folclor sino también una audaz y creativa cantautora y poeta decimista, sin hablar de sus logros en la pintura y los telares, volviéndose no solo la madre de los cantores chilenos sino también la madre de las arpilleristas y artistas gráficos populares. ${ }^{7}$ En este sentido, ha llegado a ser reconocida por ser producto y a la vez productora de una cultura auténtica, cualidad ésta muy codiciada en una sociedad moderna y capitalista en la que la mercantilización de los productos culturales

\footnotetext{
${ }^{5}$ En todo esto tiene muchas similitudes con la artista mexicana Frida Kahlo, también venerada como un ícono de la mujer latinoamericana (véase, por ejemplo, Monsiváis 2008 y Zarzycka 2006).

${ }^{6}$ Véase el libro clásico de Marshall Berman (1983) para una extensa discusión de cómo las dinámicas del capitalismo moderno socavan las prácticas de las culturas tradicionales.

${ }^{7}$ En este sentido es interesante cómo Violeta, en sus creaciones, simultáneamente cumple los requisitos de los regímenes de comunidad y de singularidad en el campo social del arte propuestos por Heinich (2010).
} 
es la regla y no la excepción. Así, muchos llegan a considerar la figura de Violeta Parra como una auténtica representante de las experiencias y anhelos del "pueblo" chileno, donde "el pueblo" se refiere a los miembros de las clases populares. ${ }^{8}$ Para algunos, incluso, emerge como una especie de "profetisa" en la historia del pueblo chileno (Soublette, 2017:225).

Si bien Violeta Parra fue reconocida como una auténtica voz del pueblo producto de tradiciones familiares y de su dominio del folclor chileno, esta característica se ve reforzada por las letras de las canciones de su autoría, que comienzan en la década de los cincuenta y que denuncian y evidencian las injusticias cometidas en contra del pueblo y defienden los derechos, la cultura, las identidades y los modos de vida de las clases populares chilenas, incluyendo a los pueblos originarios. Temas tales como "Yo canto a la diferencia," "La carta," "Arriba quemando el sol" y "Arauco tiene una pena" se han vuelto emblemáticas en el repertorio de la Nueva Canción Chilena, género que se inspiró en la senda que Violeta abrió, no solamente en términos de su contenido lírico libertario, sino también en su empleo de instrumentos de cuerda y viento de otras regiones latinoamericanas, tales como la quena y el charango del altiplano andino y el cuatro de los llanos venezolanos y colombianos, pues fue ella quien introdujo este tipo de instrumentos en el país tras sus múltiples viajes y estancias en el extranjero. Asimismo, Violeta fue reconocida como la madre de la Nueva Canción Chilena por sus principales exponentes, entre ellos Víctor Jara, Patricio Manns y sus propios hijos Ángel e Isabel (González, Ohlen y Rolle, 2009; Rodríguez, 2015 y Subercaseaux, 2017). Además, el rol que jugó este género musical al apoyar el proyecto socialista de la Unidad Popular lo convirtió en la banda sonora de la izquierda chilena, no solamente durante el gobierno de Allende sino también durante los años de resistencia a la dictadura pinochetista (Arias y del Campo, 2009; González, 2016; Jordán, 2009), con lo que se afianza aún más la posición de Violeta como una icónica voz en defensa de la libertad y la justicia social. A esto podemos agregar el internacionalismo de Violeta, adquirido por sus viajes a Europa para participar en grandes festivales mundiales auspiciados por los partidos comunistas de mediados del siglo XX, de los que escribió en sus décimas, ${ }^{9}$ y los contactos que tuvo con artistas y activistas durante sus residencias en París. O sea, Parra desarrolló una visión ampliamente cosmopolita más allá de ser una maestra de lo profundamente chileno, una visión que compartió con otras figuras de su época, tales como Mistral y Neruda, y que vemos ilustrada en canciones como "Que dirá el Santo Padre", escrito en honor al comunista español Julián Grimau y "Ayúdame Valentina", sobre la astronauta soviética Valentina Tereshkova.

\footnotetext{
${ }^{8}$ Véase las discusiones de este punto en Agosín y Blackburn 1988; Arguedas 1968; Contreras Román 2016; Epple 1977; Palominos 2017; Soublette 2017; y Verba 2013).

9 Véase, por ejemplo, la décima que se vuelve "Canción final" de la obra Canto para una semilla de Luis Advis y también Verba 2013.
} 


\section{Evolución de los homenajes a Violeta Parra los 5 de febrero}

En el medio siglo que ha transcurrido después de su muerte en 1967, se han realizado incontables homenajes a Violeta Parra, quien hoy es universalmente reconocida como una de las más importantes creadoras a nivel musical, artístico y literario en la historia chilena y de toda América Latina. En este último año en Chile, que corresponde al centenario de su natalicio, se han masificado y oficializado los homenajes a la figura y al legado de Violeta, pero no siempre ha sido así. En este trabajo, enfocamos el análisis exclusivamente en los homenajes populares y de pequeña escala que se han realizado anualmente frente a su tumba en el Cementerio General de Santiago cada 5 de febrero. Estos homenajes han sido realizados por cantores, folcloristas, poetas, gente de teatro, bailarines, artistas y luchadores sociales de izquierda, con poca publicidad y sin contar con apoyos financieros o logísticos provenientes de instituciones gubernamentales, partidos políticos u ONGs. Al parecer, los homenajes del 5 de febrero comenzaron a realizarse en los primeros años después de la muerte de Violeta y han proseguido sin mayores interrupciones hasta el presente día, aunque el registro de estos eventos está lejos de ser completo. En lugar de reconstruir en orden cronológico la historia de todos estos homenajes, en este trabajo dirigimos nuestra atención hacia cómo han ido evolucionando los homenajes realizados por tres colectivos musicales y artísticos que se han dedicado a honrar a Violeta Parra en la actualidad, poniendo un énfasis especial en la emergencia de un ritual popular que busca "despertar" a Violeta el día, no de su defunción, sino de su "fuga" de la vida terrenal.

Los tres colectivos, cuyas intervenciones son discutidas en estas páginas, son la Agrupación Canto General, los Cantores que Reflexionan y el Trío Memorial. Estos tres grupos comparten varías características definitorias, además de su pasión por ella y su legado. Primero, aunque son de diversas edades, sus integrantes forman parte de la llamada "Generación 80" o por experiencia propia o por las experiencias de sus familiares, sean estos madres, padres, tías o tíos. Segundo, los tres son colectivos activos, sin registro oficial ni patrocinios de parte de gobiernos, partidos políticos u ONGs, cuyos integrantes toman decisiones autónomas y consensuadas. Tercero, aunque algunos son de clase obrera y otros de las clases medias y profesionales, sus integrantes son luchadores sociales con un compromiso especial por recordar y buscar justicia por los compañeros caídos en manos de carabineros y militares, algunos con militancias partidistas y otros no. Algunos tuvieron experiencias en la lucha contra la dictadura y otros fueron demasiado jóvenes para haberlas tenido, aunque en algunos casos familiares mayores sí las tuvieron. Y finalmente, todos creen en la importancia de mantener viva la memoria colectiva de los luchadores y creadores de antaño para así ayudar a avanzar en un proyecto político por la justicia social en Chile. ${ }^{10}$

${ }^{10}$ Los resultados de investigación presentados en este trabajo se basan en información recolectada de la observación participativa en tres homenajes; la revisión de documentos, fotografías y videos provenientes de homenajes que no pude observar directamente; mi asistencia a reuniones de los colectivos a cargo de los homenajes y 20 entrevistas en profundidad a los participantes en los homenajes. 
Según las personas que actualmente participan en los homenajes a Violeta Parra, estos actos comenzaron en los años inmediatamente después de su muerte en $1967^{11}$ y siguieron durante la época del gobierno de la Unidad Popular y la larga dictadura que se impuso después del 11 de septiembre de 1973. La represión ejercida sobre la sociedad civil chilena incluyó una censura de toda expresión cultural que pudiera ser interpretada como defensa de las políticas o ideales de la izquierda del país. Lógicamente, la exhibición o interpretación pública de una gran parte de las creaciones -canciones, décimas, pinturas, arpilleras, etcétera- de Violeta Parra fue prohibida por los militares y esta censura fue especialmente severa durante los primeros años después del golpe de estado (Arias y del Campo, 2009; Spener, 2015).

La censura de la obra de Violeta les dolió especialmente a los cantores y folcloristas del país, para quienes ella era una figura materna en la práctica de su oficio. Además, algunas de las canciones de ella formaban parte del repertorio de la Nueva Canción Chilena, el género que sirvió de banda sonora para la izquierda del país durante su experiencia con la vía electoral al socialismo, y por lo mismo siguieron siendo de mucha significancia afectiva para los simpatizantes del gobierno de Allende tras su caída (véase, por ejemplo, González, 2016 y González, Ohlsen y Rolle, 2009; Spener, 2015). Debemos tener en cuenta también que muchos de los folcloristas y cantores de la época eran o habían sido militantes o simpatizantes del Partido Comunista de Chile (PCCh), uno de los principales partidos de la Unidad Popular y, durante la dictadura, una de las principales fuerzas clandestinas opositoras al régimen y en el que Violeta también había militado.

Frente a la censura y la represión de la dictadura, la veneración pública de la figura de Violeta Parra por parte de sus devotos adquirió una fuerte dimensión política de desafío al régimen pinochetista. Una de las mayores manifestaciones de esto en los años setenta fueron las romerías a la tumba de Violeta que fueron organizadas inicialmente por los integrantes de la Peña Doña Javiera, una de las múltiples peñas folclóricas que sirvieron de lugar de encuentro para los disidentes políticos durante la primera década de la dictadura (González Farfán y Bravo Chiapp, 2009) ${ }^{12}$. La primera de estas empezó espontáneamente después de una misa en honor a Violeta en la Iglesia Nuestra Señora de Lourdes en el barrio capitalino de Quinta Normal, el 5 de febrero de 1976. Nano Acevedo, cantautor, folclorista, comunista y uno de los fundadores de la peña recuerda que después de la misa se juntaron entre 70 y 100 personas en la Pérgola de las Flores para bajar caminando primero por la Avenida La Paz y luego por la Avenida Recoleta hacia el cementerio, cantando unas de las canciones "apolíticas" de Parra (véase Fotografía 1).

\footnotetext{
11 Un reportaje publicado en diario La Nación (1969:5) respalda su observación, informando que unos folcloristas homenajearon a Viola frente a su tumba el 5 de febrero de 1969, entre ellos Lautaro Parra, hermano de Violeta, y los conocidos grupos folclóricos Cuncumén y Chaguán. Como varios de los hermanos de Violeta, Lautaro también fue músico. Se exilió en Suecia después del golpe de estado, donde aún residía cuando murió en 2013. Véase http://www.musicapopular.cl/artista/lautaro-parra/. El autor le agradece a Juan Pablo González por facilitarle este recorte de periódico.

12 Aquí cabe mencionar que Violeta Parra, junto con sus hijos, fue una pionera en el establecimiento de las peñas folclóricas en Chile. Véase Torres Alvarado, 2004:62.
} 


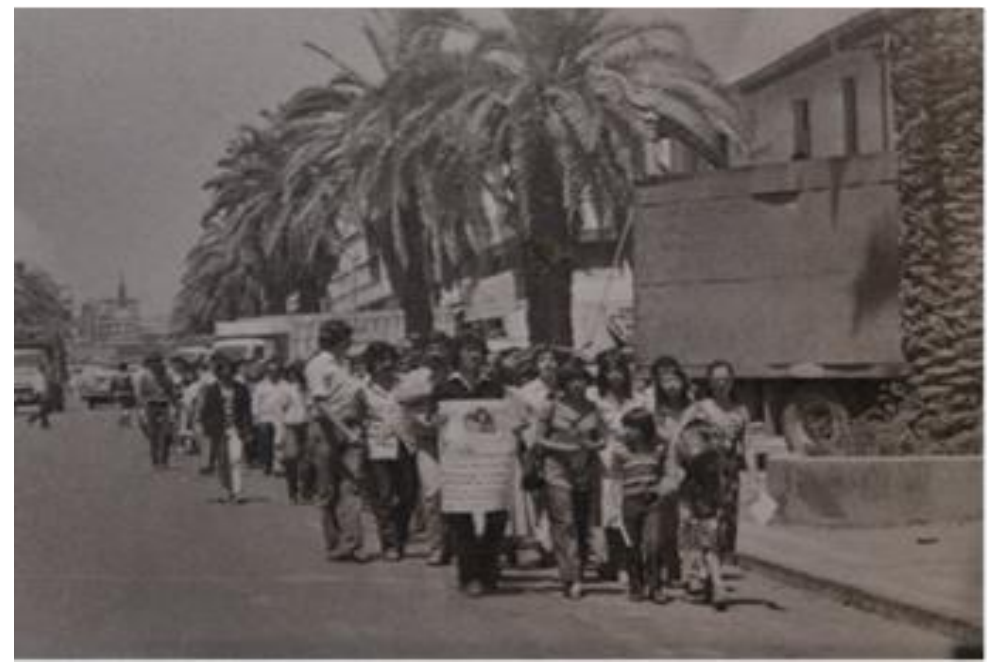

Cuando fueron parados por los carabineros -la procesión era muy visible al lado de avenidas muy transitadas- pudieron convencerles que solo eran unos folcloristas que iban a la tumba de Violeta Parra, sin ningún propósito político. Llegados a la tumba, abrieron un diálogo sobre lo que significaba el legado de Violeta y acto seguido cantaron unos temas $y$ recitaron unos versos de ella.

Fotografía 1. Romería a la tumba de Violeta Parra, febrero de 1976 (Archivo de Nano Acevedo)

Fotografía 2. Romería a la tumba de Violeta Parra en el Cementerio General, 1978 Fuente: La Bicicleta, número especial, "El Nuevo Canto Chileno: En la

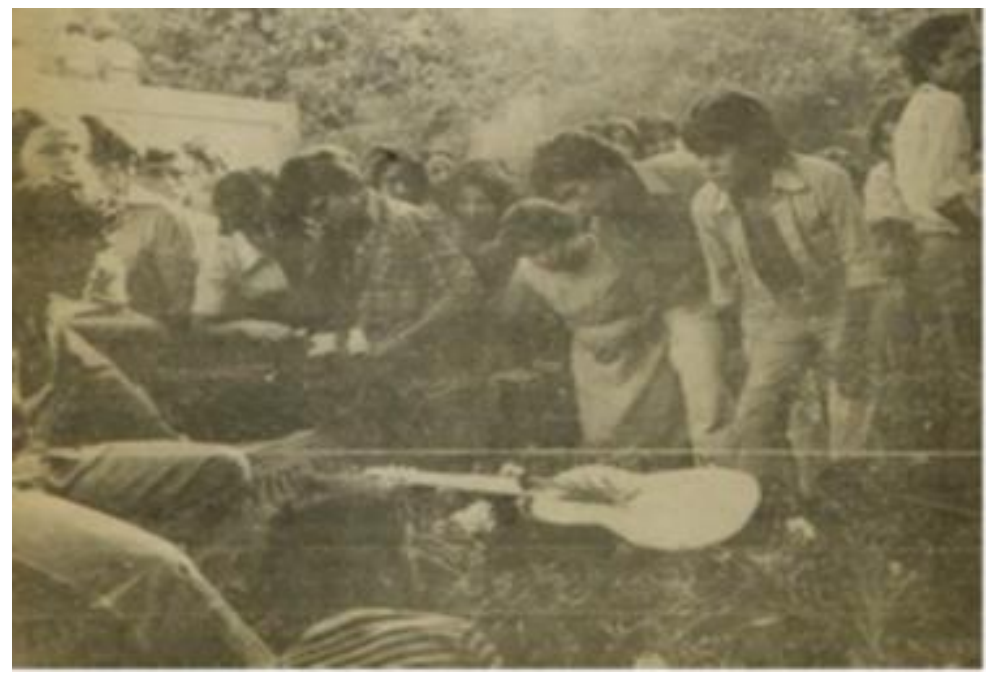
senda de Violeta" abril-mayo 1981

Al preguntársele a Acevedo cuál fue la motivación de la misa y la romería, respondió "¡Porque es la madre de todos nosotros! Violeta Parra es la más grande cantora de Chile. Y nosotros somos cantores, así que es como ir a rendir un homenaje a nuestra madre." Según Acevedo, eligieron hacer la misa y la romería el 5 de febrero en vez del cumpleaños de Parra (el 4 de octubre) porque pensaban que podía ser mucho más impactante hacerlo el día de su muerte, teniendo en cuenta la manera trágica como murió, "tan joven y abandonada."13 Realizaron tres o cuatro romerías más a la tumba de Violeta en los siguientes años (Fotografía 2) siempre el 5 de febrero, incluyendo una en la que participó el

\footnotetext{
${ }^{13}$ Acevedo proporcionó al autor información sobre las romerías a la tumba de Violeta Parra en dos ocasiones. La primera fue en una entrevista presencial en Santiago el 12 de julio de 2011 y la segunda fue en una conversación telefónica el 15 de julio de 2016.
} 
conjunto Illapu, poco antes de ser desterrado por la dictadura. Aunque no fueron actos masivos, Acevedo sostiene que la participación en las romerías les hizo muy bien a los participantes, levantando su ánimo en un momento "cuando la gente era muy temerosa."

Muchos otros ligados al folclor y al activismo político de izquierda participaron en homenajes a Violeta Parra durante los años de dictadura en Chile. Las mujeres que hoy integran la Agrupación Canto General, uno de los colectivos que actualmente organiza los homenajes a Violeta en el Cementerio General de Santiago, recuerdan cómo ellas comenzaron a participar en estos homenajes siendo jóvenes en los años ochenta, siguiendo el ejemplo de personas mayores que se habían dedicado al arte al servicio de los movimientos sociales de izquierda desde mucho antes de los años de Allende. Las tres principales representantes de este colectivo en la actualidad son la cantora Nora Blanco, la actriz y dramaturga Marcela Shultz y su hermana Maru, educadora de párvulos, artista y arpillerista. Nora, por ejemplo, recuerda haber participado en un homenaje a Violeta en el Parque O’Higgins de Santiago a mediados de los ochenta que fue organizado por el reconocido gestor cultural René Largo Farías, a su regreso al país después de su destierro en México y la Unión Soviética.

Blanco también recuerda que siempre había gente común y corriente que, durante la dictadura, iba a la tumba de Violeta en el cementerio los 5 de febrero, espontáneamente y por cuenta propia, para hacer presencia y dejarle flores. Según Nora, es importante considerar los riesgos que se corrían cantando los temas de Parra en público durante los años de mayor represión. Dice ella que se entendía que cantar los temas de Violeta Parra era una forma de protesta y "la gente entendía por qué lo estabas haciendo. Cuando la gente cantaba una canción de Violeta Parra contigo, era una forma de decir que 'estamos aquí y vamos a seguir adelante y vamos a seguir luchando.",14

Marcela Shultz, santiaguina que tenía 13 años cuando ocurrió el golpe de estado, recuerda haber participado en romerías a la tumba de la Violeta en los años setenta, organizadas por gente mayor, cuando era alumna de educación media. Ella cuenta que el 5 de febrero era una fecha emblemática que los rebeldes aprovechaban para salir a protestar cantando. Posteriormente, ya estando en la universidad, Marcela siguió su activismo, inscribiéndose en las Juventudes Comunistas, cuyos integrantes también solían participar en dichas romerías, debido a sus vínculos con los pobladores y comunidades obreras, para quienes Violeta era una figura venerada.

\section{Despertando a Violeta: La Agrupación Canto General}

Marcela Shultz cuenta que ella y sus compañeras heredaron la práctica de "despertar" a Violeta el día de su "fuga" de dos reconocidas figuras de las artes chilenas, el cantor Richard Rojas y el coreógrafo Sergio Garrido, ambos militantes comunistas, quienes de manera íntima y anónima comenzaron a ir por su cuenta a la tumba de Violeta cada 5 de febrero en los años inmediatamente después de su muerte y siguieron esta costumbre, en la medida que podían, durante la dictadura en la década de los ochenta. Richard Rojas, folclorista, cantautor y líder del Grupo Lonqui, fue un destacado exponente de la Nueva

\footnotetext{
${ }^{14}$ Entrevista con el autor en Santiago de Chile, 22 de junio de 2011.
} 
Canción Chilena, que compartió el premio por la mejor canción ("La chilenera") con Víctor Jara ("Plegaria a un labrador") en el primer festival de la Nueva Canción Chilena en 1969. ${ }^{15}$ Sergio Garrido, por su parte, fue un respetado bailarín y coreógrafo que fue también integrante durante muchos años del conjunto folclórico Aymará, un referente en el llamado Canto Nuevo (véase Díaz-Inostroza, 2007; Godoy y González, 1995; González Farfán y Bravo Chiapp, 2009), el género musical con raíz folclórica que predominó en las peñas y en el movimiento de resistencia en Chile durante la dictadura. ${ }^{16}$ A diferencia de muchos artistas comunistas de renombre de la época, Rojas y Garrido nunca se vieron obligados a abandonar el país y lograron seguir militando y luchando contra el régimen desde adentro, a la vez que practicaban sus respectivos oficios. Aunque fueron considerablemente menores que ella, Rojas y Garrido conocían a Violeta Parra personalmente y habían sido habitués de su carpa en La Reina en el año antes de su muerte.

Después de concluida la dictadura militar, Rojas y Garrido siguieron con su costumbre de ir a "despertar" a Violeta en su tumba el día de su "fuga," cantándole, recitando su poesía y tomando un vino con ella. Esta manera de acercarse a Violeta transmitía que en realidad nunca se había muerto, solo se había escondido y que, aunque invisible, su espíritu podía ser despertado, al igual que el del pueblo. Recuerda Marcela lo que Garrido y Rojas les dijeron a ella y a su hermana Maru cuando las invitaron a participar en los homenajes con ellos después de terminada la dictadura: "Lo que nosotros hacemos en el fondo es despertar a la Violeta. ... Hay que bailar cueca y cantar fuerte para que la Violeta despierte y nos enseñe el camino del año."17 A Maru no le pareció raro que realizaran el homenaje el día de la muerte de Violeta, pues las personas que oponían resistencia a la dictadura clandestinamente desarrollaron otra relación con la muerte a raíz de los riesgos que enfrentaban todos los días. Dice que la desaparición de tantos compañeros hizo que la muerte fuera "pan de todos los días" y que lo mismo le podía pasar a uno en cualquier momento. Por eso "uno aprendió a vivir el momento, el día, el instante." Además, insiste Maru, la práctica de este ritual en el Cementerio General es muy congruente con las tradiciones populares en Chile, tradiciones a las que Violeta misma se dedicó a rescatar y practicar como folclorista:

Es una cosa muy popular, además...la muerte en lo popular, era lo que hacía la Violeta, el cantar en el funeral, y tomarse el gloriado, iy todo eso es muy del pueblo! Eso de ir al cementerio y de cantar y dejar flores y de acordarse de ella y llevarle regalos de cosas que a ella le gustaban, es muy, muy del pueblo. ¡Por eso lo hacemos! Porque si no lo hacemos estamos como cortando alguna cadena que empezó hace muchos años. Y esa cadena afortunadamente no se ha roto hasta ahora. Entonces no lo podemos dejar. ${ }^{18}$

\footnotetext{
${ }^{15}$ Véase http://www.musicapopular.cl/artista/richard-rojas/ para mayor información sobre la vida y trayectoria artística de Richard Rojas.

16 Véase http://www.musicapopular.cl/grupo/aymara/ para mayor información sobre la trayectoria del conjunto Aymará. Los interesados también pueden consultar Prieto, Masmar y Calvo (2013).

${ }^{17}$ Entrevista telefónica con el autor, 18 de abril de 2016.

${ }^{18}$ Entrevista con el autor en Santiago de Chile, 22 de julio de 2011.
} 
Y, según estas tres herederas de la tradición comenzada por sus antecesores, para la misma Violeta Parra la muerte no fue "ningún drama," algo que les había comentado Silvia Urbina, compañera folclorista de Violeta. Sus demás amigas y amigos recordaron que muchas veces, cuando surgía el tema de la muerte, Violeta decía "Uno tiene que decidir su muerte, ¡mandarla! No que la muerte venga a uno” (Sáez 2012: 165).

En efecto, Garrido y Rojas habían invitado a Marcela, Maru y Nora a participar en sus homenajes con la intención de pasarles la batuta y así asegurar que esta tradición continuara, seguramente conscientes de su propia mortalidad, pues Rojas nació en 1934 (y murió en 2005) y Garrido nació en 1928 (y murió en 2008). Con ellos y otros artistas, las tres mujeres llegaron a formar la Agrupación Canto General, ${ }^{19}$ un grupo ad hoc y sin ningún presupuesto que se dedicaba a una variedad de actividades en apoyo a las luchas sociales en el período pos-dictadura y cuyo proyecto "estrella" era el homenaje a Violeta los 5 de febrero. En los primeros años de su colaboración con Blanco y las hermanas Shultz, Garrido y Rojas tomaron el liderazgo en la organización del homenaje. Siempre seleccionaban los temas que se debían desarrollar en relación con la obra y legado de Violeta. Un año, por ejemplo, destacaron la cueca y en especial las de Violeta; otro año fueron los derechos humanos y otro más el tema de la lucha de los mapuches. Rojas se encargaba de poner las canciones y Garrido de la escenificación (Fotos 3 y 4).

Fotografía 3. Richard Rojas y su esposa Ester cantando en el homenaje de la Agrupación Canto General en 2004 o 2005 Fuente: Colección de fotos de María Isabel Shultz

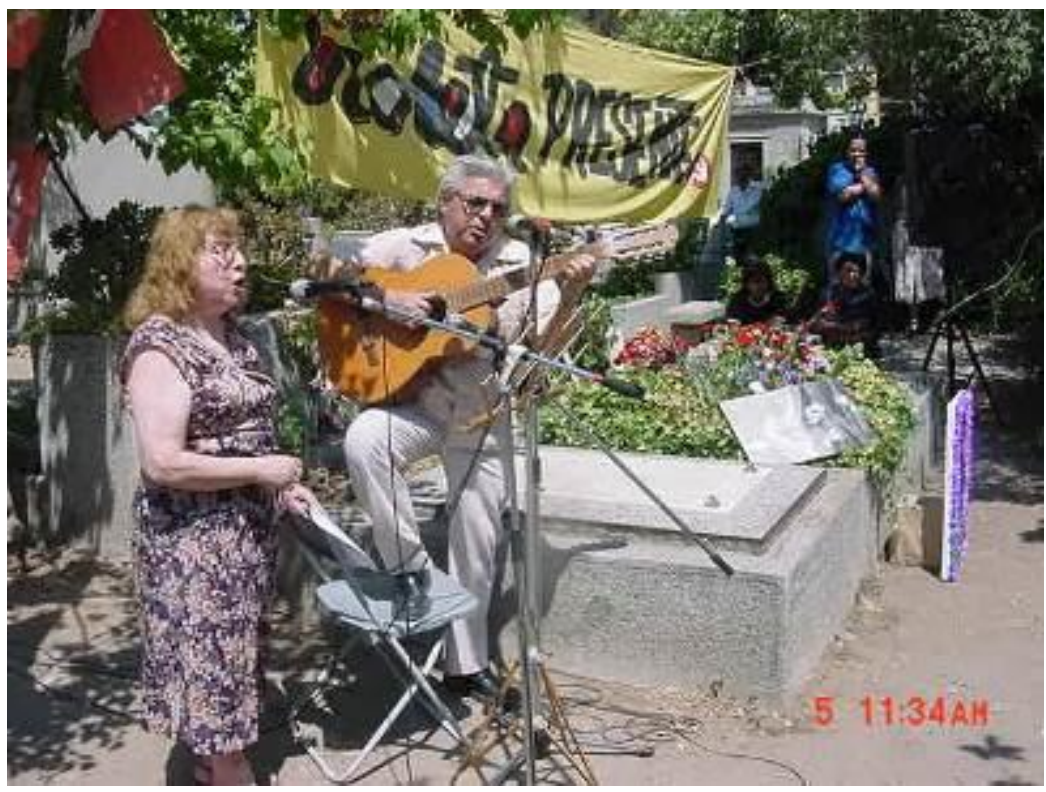

\footnotetext{
19 Además de ser una clara referencia a la obra maestra de Pablo Neruda, decidieron llamarse Canto General porque la agrupación abarcaba todas las artes, o sea no solamente el canto sino también la música, poesía, baile, teatro y las artes plásticas.
} 


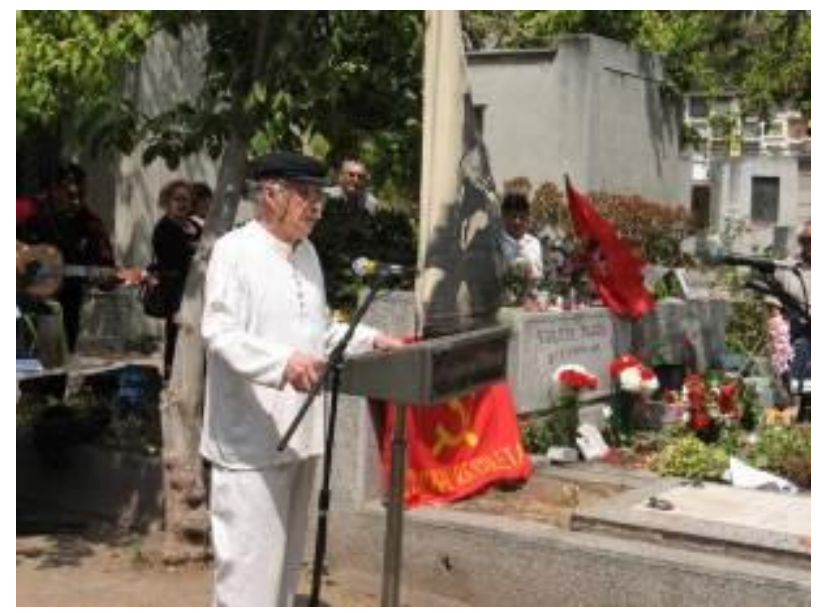

El ambiente era informal, acogedor e invitaba a la participación del público. Se cantaron varias de las canciones más conocidas de Violeta, entre ellas "Gracias a la vida," "Arriba quemando el sol" y "Arauco tiene una pena." Se brindó en honor a la memoria y al ejemplo de Violeta, se recitaron algunos de sus versos y se bailaron unas cuecas. Marcela Shultz fungió como maestra de ceremonias y cantaron, entre otras personas, Nora Blanco, Pelusa Rayen y algunos de los integrantes del conjunto Aymará en el que había participado Sergio Garrido hasta su muerte en 2008. Aunque era evidente que muchos de los presentes se conocían entre sí, también había personas, algunas que parecían ser bastante humildes, que se habían acercado a la tumba de Violeta sin saber que se organizaba un homenaje formal ahí ese día. Llegó inesperadamente un miembro del Sindicato de Folcloristas que regaló unas cuecas y cuentos al público, quienes reaccionaron con mucha alegría. Se le acercaron al único "gringo" presente en el evento para preguntarle cómo había llegado y si algo sabía de Violeta Parra. Cuando se supo que el gringo efectivamente sabía quién era Violeta y que él era cantor también, le prestaron una guitarra y dijeron que subiera al escenario para cantar uno de sus temas. Esta inclusión en el homenaje de gente que llegaba inesperadamente fue una práctica que los actuales integrantes de Canto General también habían heredado de sus mentores Garrido y Rojas.

Tal y como se describió anteriormente, los integrantes de la Agrupación habían aprovechado la ocasión para rendir cuentas a Violeta sobre los grandes acontecimientos en la vida nacional chilena del último año, ligándolos con las canciones y décimas de ella (Ver fotos de la serie 6a-f y $7 \mathrm{a}-\mathrm{f}$ al final del texto). Como se puede apreciar, lograron presentar esta relación entre la obra de Violeta y los sucesos actuales al colocar unas cartulinas en unos postes alrededor de la tumba de ella, con los temas y los versos relevantes escritos a mano. Así, los asistentes pudieron acercarse para leer un recuento de la historia del año pasado (o sea 2010-2011), presentada en las palabras de Violeta, quien de alguna manera había demostrado ser una especie de clarividente. Las cartulinas presentaron, por ejemplo, el terrible terremoto del 27 de febrero de 2010; la asunción a la presidencia del primer candidato derechista en la pos-dictadura el 11 de marzo de 2010; los 82 días de huelga de 
hambre de los comuneros mapuches encarcelados; y los 33 mineros atrapados en las profundidades de una mina por 70 días en Copiapó, en el norte del país. Dice Nora Blanco que "Las canciones de Violeta siguen estando vigentes. Para cada cosa que pasa en este país, hay una canción de Violeta que ya lo está diciendo. Y eso te indica que ya pasó y se vuelve la historia a repetir. Así con sus canciones podemos tocar todos los acontecimientos del año, entonces te puedes imaginar, es una actividad política. ¡Esa era la idea!” El acto, que había comenzado alrededor de las once de la mañana, terminó a eso de las dos de la tarde. Después de despedirse del público, los participantes del homenaje partieron al mercado popular La Vega para comer, conversar y seguir cantando, pasando una guitarra de mano en mano en la mesa.

Pasaron varios años antes de que yo pudiera volver a asistir a un homenaje organizado por la Agrupación Canto General. No obstante, mantuve contacto con las integrantes del colectivo en el interino durante breves visitas a Santiago en 2013, 2014 y 2015, además de contactos vía electrónica y telefónica. Además, pude revisar muchas fotografías, comentarios y videos en línea que la Agrupación subió a las redes sociales después de "despertarle" a Violeta el 5 de febrero. La estructura de los homenajes de los años a los que no pude asistir presencialmente fue la misma. Finalmente, pude asistir y participar en otro "despertar" de Violeta el 5 de febrero de 2016. El tema que escogieron para el acto de 2016 fue "La Unidad de los Pueblos Americanos" y lo ilustraron a través de una gran arpillera de un mapa del continente adornado con fotos de los cantores "comprometidos" en cada país que habían seguido las huellas que Violeta dejó. ${ }^{20}$ Además de cantar temas de Violeta misma, le cantaron a ella y al público otros temas del cancionero latinoamericano, tales como "Yo soy de un pueblo sencillo" de Nicaragua y "Canción con todos" de la Argentina. Y claro que la cueca "Los pueblos americanos" de Violeta fue cantada y bailada por los participantes y miembros del público al final (Ver figura 1 invitación y Fotografías serie $8 \mathrm{a}-\mathrm{f}$ al final del texto $\mathrm{y}$ video https://www.youtube.com/watch?v=VoD3wtu9rI8

En años recientes, han aparecido al menos dos colectivos más en la región metropolitana de Santiago cuyas actividades incluyen homenajear a Violeta Parra los 5 de febrero en el Cementerio General. En ambos casos sus actividades han coincidido de alguna manera con las de la Agrupación Canto General, en un caso de manera directa desde el comienzo y en el otro caso de manera paralela algunas veces y directa en otras ocasiones. El primero de estos dos colectivos son Los Cantores que Reflexionan y el segundo es el Trío Memorial. Revisemos brevemente la historia de cada uno de estos colectivos y su llegada a los homenajes a Violeta Parra.

\section{Los Cantores que Reflexionan}

El colectivo Los Cantores que Reflexionan nace de la participación de varios de sus integrantes en el evento Mil Guitarras para Víctor Jara, homenaje multitudinario al fallecido cantautor, que tiene lugar anualmente en la comuna de Recoleta, colindante con el

\footnotetext{
${ }^{20}$ Por ejemplo, Daniel Viglietti y Alfredo Zitarrosa en Uruguay, Atahualpa Yupanqui y César Isella en
} Argentina y Joan Báez y Pete Seeger en Estados Unidos. 
Cementerio General de Santiago, desde septiembre de 2013. El guitarrista Mauricio Gutiérrez, santiaguino de 50 años, quien había participado en Mil Guitarras en 2013 y de nuevo en 2014, pensaba que era triste que se organizara un mega-acto en honor a Víctor Jara a fines de septiembre todos los años sin que hicieran nada para honrar a Violeta el día de su cumpleaños solamente una semana después. Decidió tomar la iniciativa y subió una invitación al Facebook de Mil Guitarras para juntar un grupo de cantores el 4 de octubre frente a la tumba de Violeta para cantar doce temas de ella de un cancionero artesanal que Gutiérrez compiló. Además, imprimió unas fichas (ver Figura 2) que repartió en el evento Mil Guitarras para Víctor Jara 2014 convocando a la gente para que se juntara después de Mil Guitarras y fueran a cantarle a Violeta en el Cementerio el día de su cumpleaños la siguiente semana. Tomó la decisión de llamar el evento "Cantores que Reflexionan" por el mensaje que expresaba esta canción de Violeta, que según Gutiérrez "representaba el espíritu del cantor que es más consciente, que no habla cosas banales, como que la letra de la canción lo dice todo, que digamos." ${ }^{21}$ A fin de cuentas alrededor de 25 personas participaron en el "recital" en la tumba de Violeta el 4 de octubre de 2014. Después se volvieron a juntar los participantes en una picada famosa llamada La Piojera para reflexionar sobre la experiencia de haberse unido para cantar y guitarrear con Violeta.

Había mucho entusiasmo para seguir juntándose y buscar otras oportunidades de cantar en público. Y así nació el colectivo, que al momento en que entrevisté a varios de sus integrantes en marzo de 2016, contaba con la participación estable de alrededor de 15 personas. El colectivo empezó a cantar, de manera gratuita, en eventos de derechos humanos, de cultura popular y de causas políticas de izquierda. El número de actividades y ensayos del colectivo se multiplicaron tan rápidamente que muy pronto Mauricio Gutiérrez tuvo que retirarse del colectivo, pues interfería demasiado con sus compromisos como músico profesional. Teniendo en cuenta los orígenes y las características del colectivo, no sorprende que fueran a la tumba de Violeta para cantarle el próximo 5 de febrero de 2015. Llegaron justo cuando la Agrupación Canto General terminaba su homenaje anual. Fue un grato encuentro y en el que los integrantes de los Cantores participaron en el final del homenaje de la Agrupación y los integrantes de la Agrupación se quedaron para sumar sus voces a las de los Cantores. ${ }^{22}$ No sorprende que la gente de la Agrupación invitara a los Cantores a juntar fuerzas para despertar a Violeta el siguiente 5 de febrero de 2016, el 49 aniversario de su fuga.

\section{El Trío Memorial}

Primero que nada, hay que aclarar que el Trío Memorial no es un trío en el típico sentido musical, sino un colectivo de luchadores sociales y de creadores de múltiples disciplinas, incluyendo la música, el baile, la poesía, el teatro y las artes plásticas. No obstante, su principal quehacer es la música y en especial el canto comprometido al servicio de los

\footnotetext{
${ }^{21}$ Entrevista con el autor en Santiago de Chile, 30 de marzo de 2016.

${ }^{22}$ En realidad, en años anteriores, al menos dos de los actuales Cantores habían participado como invitados en uno de los homenajes a Violeta organizado por la Agrupación Canto General, aunque estos no sabían que iban a toparse con la gente de la Agrupación en el cementerio en ese preciso momento.
} 
derechos humanos. El concepto de "trío" en su nombre simboliza la unión entre el público, los intérpretes del colectivo y los caídos que lucharon contra la dictadura pinochetista. El vocero y director musical del Trío es Nino Vásquez, quien entre otros oficios que practica es cantor de micro. De hecho, lideró un grupo de cantores que fueron a cantarle a Violeta el 5 de febrero de 2007, integrándose espontáneamente al acto organizado por la Agrupación Canto General (véase Fotografía 5).

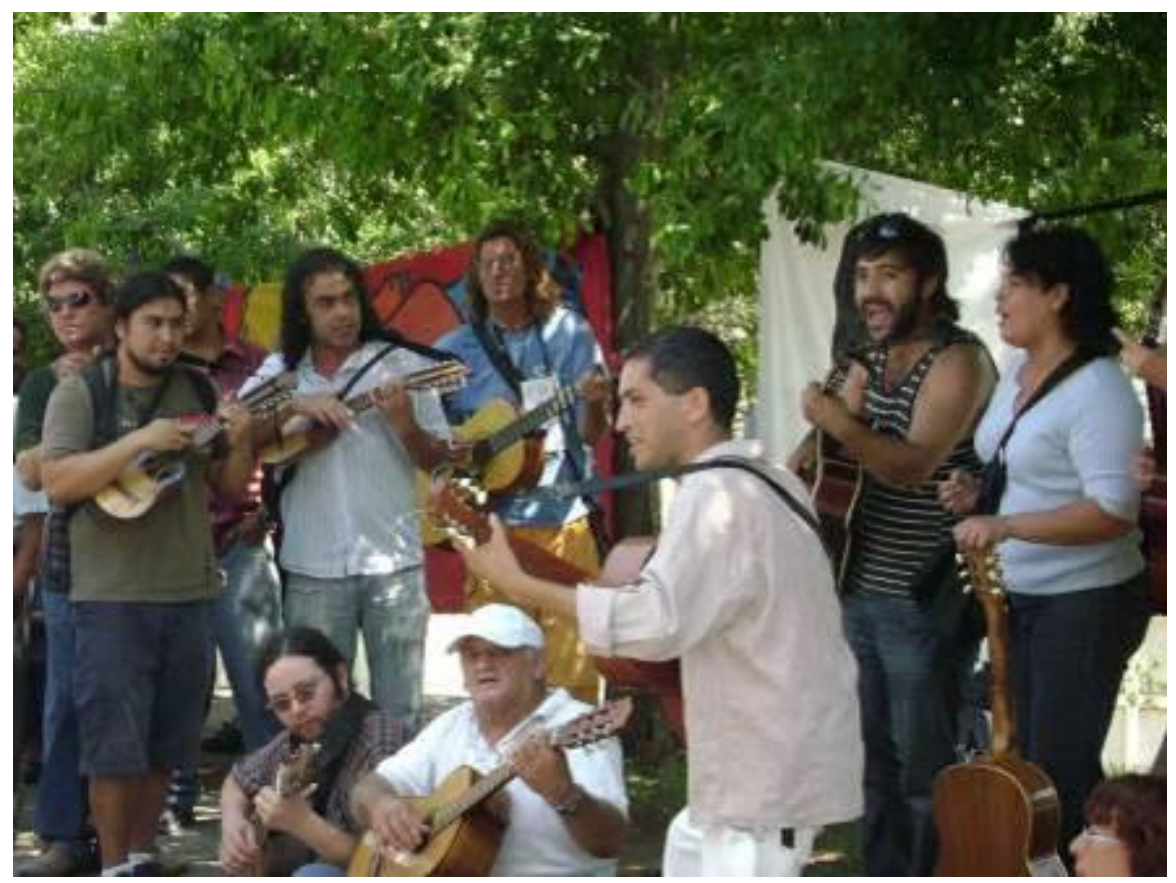

Fotografía 5. Cantores de micro llegan a cantar en el homenaje de 2007 Fuente: Colección de María Isabel Shultz

Según Nino, el Trío se dedica, a través del trabajo cultural, a contribuir a la construcción de "la sociedad justa por la que los caídos cayeron." 23 Uno de los compañeros de Nino en el Trío, Lucho González, abunda sobre este punto, aseverando que el trabajo del Trío es comunicar a los jóvenes que "los muchachos de 17 o 18 años que están desaparecidos no eran blancas palomas, sino revolucionarios que desaparecieron combatiendo." 24 El Trío Memorial nace por una iniciativa de Nino y varios otros compañeros hacia fines de 2011, cuando terminaron otro proyecto cultural llamado La Obrera, donde trabajaron durante un par de años bajo el alero de la Fundación Víctor Jara. Cuando yo conocí el trabajo del Trío, hacia principios de 2016, estaban elaborando un montaje de canciones de Violeta repensadas en términos musicales para llegar a un público de jóvenes del siglo XXI, con un compás más acelerado, ritmos más fuertes y armonías menos tradicionales. El nuevo montaje se llamaba ;Violeta vive Viva Violeta! y lograron

\footnotetext{
${ }^{23}$ Entrevista con el autor en Santiago de Chile, 26 de febrero de 2016.

${ }^{24}$ Entrevista con el autor en Santiago de Chile, 5 de abril de 2016.
} 
presentarlo en varios escenarios de Santiago y Valparaíso en el transcurso del año. El 6 de febrero de 2016, el Trío Memorial organizó su propio homenaje a Violeta en su tumba en el Cementerio General, con varios invitados, incluyendo a cantores, poetas y bailarines (Ver Figura 3, Fotografías 9a-f y video https://www.youtube.com/watch?v=7oW96wRaSqc)

En el homenaje estrenaron algunos de los temas que habían arreglado para el nuevo montaje en honor a Violeta. A diferencia de la Agrupación Canto General, que siempre rendía sus honores a la Violeta en la fecha precisa de su partida, el Trío Memorial no tuvo ningún problema para calendarizar su homenaje el fin de semana más cercano a la fecha. En 2016, el 5 de febrero caía un día viernes y Trío Memorial fijó su evento para el día siguiente, permitiendo así la asistencia de un público que tenía que trabajar en la semana.

\section{El 50 aniversario de la fuga de Violeta Parra}

El 5 de febrero de 2017 marcó el aniversario cincuenta de la "fuga" de Violeta Parra. En esta ocasión, los tres colectivos analizados en este trabajo -Agrupación Canto General, los Cantores que Reflexionan y el Trío Memorial- juntaron fuerzas con otros dos colectivos -Liberarte y Mujeres de Colores- para hacer un homenaje en grande a Violeta, que comenzó a las once horas y no terminó hasta las seis de la tarde (ver Figura 4 al final del texto). Además de los participantes de estos colectivos, se invitó a muchos otros músicos y artistas quienes aportaron al evento sus considerables talentos. Como siempre ha sido el caso en los homenajes en el Cementerio General, los participantes en el evento provenían del mundo de la cultura popular, es decir que, aunque algunos vivían de su arte y producían obras de gran calidad, ninguno había llegado a ser famoso a nivel nacional. $O$ sea este homenaje, aunque involucró la participación de mucha más gente y duró más tiempo que en años anteriores, como siempre fue un evento comunitario, auto-gestionado y a nivel de base sin ninguna compensación monetaria para los participantes. ${ }^{25}$ Cecilia Concha Laborde, cantautora y activista comunitaria, llegó a participar en los homenajes del 5 de febrero solamente en años recientes, pero jugó un papel importante en coordinar el acto del 50 aniversario de la partida de Violeta. Según ella, hubo ciertas reservas de parte de cada colectivo en cuanta a preservar el particular carácter político y popular que cada uno impartía en sus homenajes anteriores, pero, a pesar de algunas discrepancias, pudieron resolverlas poniendo a cada colectivo a cargo de un bloque del programa, permitiéndo así a cada uno incorporar su particular sello en la parte del programa que le correspondía. Cecilia reconoce que fue "un esfuerzo generoso de parte de todos durante el día entero," con todos los grupos usando un mismo sistema de sonido, una difusión y publicidad compartida y "un hilo conductor" que unía los varios bloques del programa. ${ }^{26}$

\footnotetext{
${ }^{25}$ El autor no pudo asistir al homenaje del aniversario $50 \mathrm{y}$, por lo mismo, no se presentan fotos del evento en este documento. No obstante, muchas imágenes y reportajes sobre el evento se encuentran en línea. Pueden consultar, por ejemplo, un reportaje en http://radionauta.online/violeta-parra-a-50-anos-de-su-fuga/, un video en https://www.youtube.com/watch?v=7DLGuR8CSbA y otro video más en https://videos.telesurtv.net/video/644027/el-pueblo-de-chile-honra-a-violeta-parra-a-50-anos-de-su-muerte/. ${ }^{26}$ Entrevista telefónica con el autor, 13 de diciembre de 2017.
} 


\section{Identificaciones con Violeta}

Si bien es cierto que todos los participantes en estos homenajes a Violeta la veneran por quien era y por sus aportes al arte y a las luchas populares, en muchos casos las razones de su participación van más allá del mero respeto y admiración y se relacionan con cuestiones identitarias en la dimensión afectiva de la experiencia personal y social. O sea, para muchas de las personas que participan en los homenajes discutidos en este trabajo, la figura de Violeta Parra representa cualidades con las que ellas se identifican en sus propias vidas o que aspiran a compartir con ella. Es importante destacar que estas identificaciones son más sociales que individuales, es decir, los participantes se identifican con estas cualidades principalmente en términos de su relación con su comunidad y sociedad y no tanto en el ámbito de sus vidas personales. Esto nos remite al estudio clásico de Durkheim sobre la veneración de los íconos religiosos, en el que observa que cuando los creyentes veneran al ícono de un dios lo que en realidad están venerando, subconsciente o implícitamente, es a sí mismos, o sea su propio grupo en su colectividad y las cualidades positivas que tienen o aspiran a tener (Connerton, 1989:50; Durkheim, 1971).

En mis entrevistas con los participantes de los homenajes se observan varios aspectos del carácter de Violeta Parra, como personaje e ícono, con los que se identifican en tanto activistas y artistas. En este apartado me dedico al examen de los comentarios que hicieron con respecto a 1) Violeta como auténtica cantora popular; 2) Violeta como representante del pueblo chileno y su trayectoria histórica; 3) Violeta como creadora extraordinaria; 4) Violeta como una mujer sufrida y aguerrida; y 5) Violeta como luchadora por la justicia. En las conversaciones que sostuve con los entrevistados, estos cinco temas muchas veces se combinaron en un mismo comentario, haciendo difícil hacer una correspondencia de uno a uno entre un tema y un comentario. Por lo mismo, realizaré comentarios ilustrativos de diferentes participantes en los homenajes y los analizaré en relación a cada uno de los múltiples temas que representan.

Las y los cantores en el Chile de antaño, es decir, de antes de mediados del siglo XX, cumplían, a través de la poesía popular, un papel imprescindible en la vida ritual de los pueblos que dependían de ellos, no solo por entretención, sino para todo tipo de eventos en el ciclo vital, desde los nacimientos hasta los matrimonios y los velorios (véase Alegría, 1954; Barros y Dannemann, 1958; y Dolz-Blackburn, 1984). Tal vez lo más atractivo de la figura de Violeta como cantora, desde el punto de vista de los participantes en los homenajes, es su relación directa y sin mediación con el pueblo del que era y al que servía. O sea, los cantores son vistos como auténticamente populares y Violeta Parra es reconocida como la figura clave en el rescate de este oficio antes que desapareciera debido a la urbanización de la población chilena durante el transcurso del siglo XX. A su vez, las y los cantores que han participado en los homenajes, se consideran descendientes de Violeta, de acuerdo con lo que Nano Acevedo ofreció como explicación por las romerías que ayudó a organizar en dictadura: “¡Porque es la madre de todos nosotros!”

Lilia Díaz, profesora de lengua española en un colegio, cuequera, familiar de detenidos desaparecidos y veterana de las luchas clandestinas contra la dictadura en las Juventudes Comunistas y posteriormente en el MIR, actualmente es integrante del Trío Memorial y en sus comentarios sobre el porqué de los homenajes destacó la defensa de la 
cultura popular que representa Violeta Parra, comentando que ella "fue un bastión de resistencia en términos de la cultura popular en su conjunto" y agregando que "era una mujer del mundo popular, que trabajaba para el mundo popular y que no quería renunciar a él". El Trío reconoce a Violeta como una figura que hizo lo posible para que el mundo popular fuera reconocido por lo que realmente es, "un mundo muy rico en términos de figuras, de organización, de temáticas, de costumbres." 27 Nino Vásquez, el líder del Trío Memorial, hace eco de las razones que ofreció Lilia por la identificación con Violeta, resaltando un elemento adicional: la pobreza en que ella vivió. Según Nino, "muchos de nosotros hemos pasado historias de pobreza bien marcadas" y algunos las siguen viviendo, al igual que otros miles de chilenos. Además, dice Nino, Violeta les había dejado el ejemplo del colectivismo en su quehacer, "de dejar su legado para otras personas". Y recalca que Violeta "no adquirió bienes, no los adquirió ni para sus propios hijos," sino que lo había hecho todo "para dejar un legado" al pueblo. Aquí Nino nos recuerda lo que sentenció Nicanor Parra en los versos que escribió para su hermana: Viola "ni se compra ni se vende" (citado en Parra, 2009:218).

Héctor Vidal es integrante de los Cantores que Reflexionan. Se identifica muy fuertemente con Violeta en base a sus propias experiencias de vida y como éstas representaban de alguna manera las experiencias de una gran parte de los chilenos de mediados del siglo XX. Héctor nació y creció en un pequeño poblado atado a un aserradero en la cordillera, arriba de Pucón, en los años cuarenta, que posteriormente fue destrozado por un incendio forestal. Conocía la pobreza y el abandono rural en carne propia. Asistió a una escuela rural de profesores pehuenches antes de salir con su hermano a buscar oportunidades en Santiago, cuando tenía apenas 19 años de edad. Encontró trabajo en obras de construcción y trabajó duro, estudiando de noche, llegando eventualmente a ser arquitecto. Era el mayor de todos mis entrevistados, el único que ya había entrado en su octava década de vida. La entrevista con Héctor fue también una de las más conmovedoras, pues sintió mucha emoción al contar su historia y relacionarla con el ejemplo de Violeta. Dijo que se identificaba con Violeta y también con Víctor Jara porque "habían vivido las mismas miserias" que él había vivido, sufriendo todas "las inclemencias" de los pueblos olvidados del sur, una consecuencia de "vivir en el lugar más apartado del mundo, aislado. Vivieron lo que yo viví." Y recalca, diciendo “¡Eso nace de la tierra! ¡Nace de la miseria! Ahí está el arte. Como de los algodonales nace el jazz, así nace Violeta. [Rompe a llorar] Nace Víctor. Y nacen los grandes. Lo digo con modestia. Me identifico con ellos, sí." Héctor también habló de su reverencia por la capacidad creativa que Violeta tenía para expresar las verdades de la vida que ella había vivido. Comenta que "Violeta es una sola y no hay más," por la genialidad que tenía para "decir tantas verdades" tejiendo "estas palabras... que han abierto los ojos al mundo". Violeta, insiste, les había dejado "una tarea tremenda" a los integrantes del colectivo, la de comunicar estas verdades a la gente de estos días para que "no sea tonta y no sea lesa" con respecto a los retos políticos y a la explotación que enfrentan. ${ }^{28}$

\footnotetext{
${ }^{27}$ Entrevista con el autor en Santiago de Chile, 31 de marzo de 2016.

${ }^{28}$ Entrevista con el autor en Santiago de Chile, 28 de marzo de 2016.
} 
Uno de los temas sobresalientes en las entrevistas a los participantes en los homenajes fue cómo muchas de las mujeres se identificaban intensamente con la figura de Violeta como mujer y en particular con el tipo de mujer que ella representaba. Lilia Díaz, del Trío Memorial, citada arriba, resume en pocas palabras una actitud que parece ser más general entre las mujeres entrevistadas, que como mujer Violeta representaba a las mujeres inconformes con el papel que se les asignaba en una sociedad patriarcal: "Crea desde su manía de mujer, canta desde su manía de mujer, establece las relaciones humanas dentro de su infierno personal y yo creo que es esto que me hermana con ella, este malestar permanente en relación a lo que se ve". La cantora Alexandra Acuña participó como intérprete invitada en el homenaje organizado por el Trío Memorial el 6 de febrero de 2016 y, al igual que Cecilia Concha Laborde, es una de las integrantes de Mujeres de Colores, uno de los colectivos que convocaron el homenaje del 50 aniversario de la fuga de Violeta. $\mathrm{Su}$ visión de Violeta como mujer ratifica la postura de varias de mis entrevistadas. Para ella, Violeta fue "una mujer fuerte, anteponiéndose a todas las vicisitudes que pudo haber tenido en el momento que vivió". Cree que no hay ninguna mujer consciente en Chile "que no se identifique con Violeta Parra". De alguna manera, dice que "muchas chilenas, isomos Violeta Parra! Las chilenas que criaron a sus hijos solas. La Violeta Parra tuvo que hacer miles de cosas para poder comer: "Hizo cualquier oficio, cualquier cosa para poder subsistir". Al igual que otras entrevistadas, piensa que Violeta representa a la mujer de América Latina en general. Dice que hay un elemento que comparte toda mujer luchadora del continente con ella, "el ser valiente, el no doblegarse, el salir adelante" a cualquier costo. $^{29}$ Pelusa Rayen, cantora, artesana y madre soltera, creció en un barrio popular en la comuna de Recoleta. Después del golpe hubo mucha represión en su barrio y primero su hermano mayor y luego ella se incorporaron al MIR, aun siendo adolescentes, para sumarse a la resistencia. Ha participado en varios homenajes a la madre de las y los cantores, uno de ellos como invitada de la Agrupación Canto General, donde yo la conocí en 2011. Ella se identifica fuertemente con Violeta por las mismas razones que Lilia Díaz y Alexandra Acuña ofrecieron. No obstante, agrega que Violeta sufrió un dolor especial que muchas mujeres latinoamericanas comparten con ella: el amor por los hombres que no le correspondían y no la respetaban. La considera una tremenda paradoja en la vida de una mujer de carácter tan fuerte y aguerrido. "Era enamoradísima, la verdad era enamorada," dijo. "Fue su punto débil.", 30

Las y los participantes en los homenajes del 5 de febrero también se identifican con la figura de Violeta Parra por su compromiso con las luchas por la justicia social, un compromiso que comparten ellos y que les motiva a cantar los temas de ella y otros

\footnotetext{
${ }^{29}$ Entrevista con el autor en Santiago de Chile, 22 de marzo de 2016. Cabe mencionar que Acuña, al igual que varias integrantes de los colectivos analizados en estas páginas, participó en la grabación de un triple CD titulado Herencia rebelde: Trovadoras en la ruta de Violeta, un proyecto iniciado por Cecilia ConchaLaborde. El 28 de diciembre de 2017, unas 16 cantoras chilenas y argentinas cantaron las canciones que habían escrito en honor a Violeta Parra que estaban incluidas en el CD.

Véase https://www.espacioregional.cl/single-post/2017/12/29/Violeteras-Herencia-Rebelde-Disco-tributo-aVioleta-Parra-en-su-centenario-de-natalicio-con-51-canciones-originales.

${ }^{30}$ Entrevista con el autor en Santiago de Chile, 27 de marzo de 2016. Sobre esta vulnerabilidad de Violeta en cuestiones de amores, véase también Montecino, 2017:55-61.
} 
cantautores que siguieron su ejemplo. La mayoría de los participantes en los homenajes sigue pensando que la canción sirve como un arma de lucha política y que las canciones de Violeta Parra siguen siendo vitales en su quehacer político-artístico. Según Boris Barrera, militante comunista y veterano de las luchas clandestinas contra la dictadura y actualmente integrante de los Cantores que Reflexionan, "si tú quieres escribir o cantar algo sobre lo que está pasando ahora, tienes la opción de hacer tú la canción o ir a dónde Violeta y ahí con seguridad encuentras una canción que expresa -ipero calcado!- lo que pasa ahora."31 Miguel Rozas, otro integrante de los Cantores, siempre se ha dedicado profesionalmente a la educación pública y actualmente funge como funcionario en el Ministerio de Educación. Era adolescente cuando ocurrió el golpe de estado en 1973 y después de completar la educación media militó por un breve tiempo en un pequeño partido de izquierda, época cuando también participó en varios conjuntos de música folclórica y de canto nuevo. Su participación en los Cantores que Reflexionan representa un retorno a la vida musical que llevó cuando joven, después de criar a sus hijos y dedicarse a su carrera profesional. En una entrevista colectiva con los Cantores, comentó que la música sirve como una militancia política y cultural para él, una postura que fue secundada inmediatamente por varios de sus compañeros. Dijo Miguel que "para mí la música, de la Violeta y de Víctor, es una militancia. Es mi manera de militar, es mi manera de contribuir y de aportar a los procesos de cambio social y de mayor justicia social." 32

Para algunos de los participantes en los homenajes, su canto como militancia fue más literal. Pelusa Rayen se dedicó a cantar en las micros en los ochenta como parte de su resistencia al régimen militar en las filas del MIR. Asevera que la figura de Violeta fue una inspiración moral y una fuente de valentía para ella y sus compañeros de canto frente a la represión en los días más oscuros de la dictadura, cuyas hazañas fueron a veces realmente audaces:

La Violeta fue un gran apoyo psicológico, emocional, físico. ¿Sabes tú lo que significa cantar "La carta" arriba de una micro de pacos? ¿Sabes tú lo que significa eso? ¿La emoción de haber podido cantar "La carta" arriba de una micro de pacos? ¡Eran tantas las ganas que yo tenía! Fue como si yo les dijera “¡Mátenme! ¡Mátenme, si quieren! ¡Pero yo voy a cantar mi canto!” La rabia que yo tenía, de ver tanta injusticia y tanta muerte, fue increíble. Este canto fue liberador. Fue un gusto poder hacer eso.

Giovanni, el hijo de Pelusa, actualmente tiene treinta años y es cantor, guitarrista y activista estudiantil en la Universidad de Chile. Cuenta como su mamá lo había "violetizado" de niño, llevándolo a visitar la tumba de Violeta en el cementerio, enseñándole sus canciones y contándole su vida. Comenta que ve mucho de Violeta en las experiencias y forma de vida de su madre. Y también se lo ha dicho a ella. Según Pelusa, el hecho de que su hijo se dé cuenta de cómo la Violeta le ha marcado la vida la deja "acongojada," aunque le cuenta al hijo que "hay miles de Violetas en este país". De alguna manera, la Violeta le ha marcado la vida y la visión del mundo a Giovanni también. Piensa que ella fue "una genuina

\footnotetext{
${ }^{31}$ Entrevista con el autor en Santiago de Chile, 1 de abril de 2016.

${ }^{32}$ Entrevista con el autor en Santiago de Chile, 5 de marzo de 2016.
} 
creadora" y "una revolucionaria". La describe con los adjetivos "perseverante, comprometida, valiente y audaz". En cuanto a su compromiso con las luchas sociales y políticas de su pueblo, Giovanni se imagina una escena ilustrativa: "Si hubiera estado viva para el golpe de estado, no me parecería raro que Violeta hubiera ido a La Moneda con una escopeta a defender al Presidente Allende y a matar milicos. Hubiera ido con su guitarra y una escopeta atravesada en la espalda.",33

\section{Conclusión: ¿de qué sirve homenajear a Violeta Parra?}

Como se ha visto anteriormente, los homenajes que se han realizado en la tumba de Violeta Parra en el Cementerio General de Santiago durante las décadas después de su muerte en 1967 siempre han consistido en rituales relativamente íntimos, con un público y número de participantes limitados. Aunque han sido actos públicos, nunca han logrado una masividad ni una amplia difusión en los medios de comunicación, aunque algunos medios, como TELESUR en años recientes, les han dado cierta cobertura. No obstante, los entrevistados no creen que esta falta de masividad le reste importancia al acto de homenajear a Violeta, una postura que no tiene que ver solamente con la admiración y afecto que le tienen a ella y a su obra. Entonces, si no es por llegar a un público masivo ni por el simple deseo de honrar a un personaje que merece un gran respeto por lo que hizo en su vida, ¿de qué sirve homenajear a Violeta en su tumba cada 5 de febrero? Al planteárseles esta pregunta, los participantes en los homenajes ofrecieron varios tipos de respuestas que no les sorprenderán a los estudiosos del papel que juega la cultura en los movimientos sociales. En este apartado quisiera resaltar los tipos de respuestas que, a mi juicio, ayudan a que comprendamos más cabalmente los significados que otorgan los participantes al acto de rendir honores a la figura de Violeta Parra. Estos significados tienen que ver con la construcción y conservación de la memoria colectiva, sanar el trauma que muchos de los participantes experimentaron durante la dictadura y reafirmar su identidad cultural, política y generacional frente a la adversidad en estos tiempos neoliberales en Chile.

Marcela Shultz, de la Agrupación Canto General, observa que el rescate de la historia que Violeta Parra representa para el mundo de la cultura popular sigue siendo uno de los principales motivos de los homenajes. Según ella, "nuestro pueblo, nuestro país tiene una memoria cortita y una tendencia a la amnesia" que hace importante el rescate que representan los homenajes. Además, estos se han vuelto una tradición para la Agrupación y sus integrantes actuales, quienes sienten la obligación de mantenerlos en honor, no solamente a Violeta, sino también a Sergio Garrido y Richard Rojas y a los otros folcloristas y activistas que los habían iniciado. Marcela también enfatiza que el ritual de realizar el homenaje a Violeta tiene algo de "mística" para ella y sus pares. Esta mística proviene del mundo folclórico, en el que se cantaba y se bailaba cueca en un velorio y se saltaba el cajón y se zapateaba en la tumba del difunto. Dice ella que el ritual del homenaje tiene "casi un karma, que si no lo hacías no ibas a poder quedarte tranquila nunca."

Andrea Morgado, psicóloga, guitarrista, cantora y ex líder estudiantil en la Escuela de Psicología de la Universidad Central durante la dictadura y actualmente miembro de los

\footnotetext{
${ }^{33}$ Entrevista con el autor vía Facebook Messenger, 7 de julio de 2017.
} 
Cantores que Reflexionan, sugiere algo similar. Para ella, los homenajes a Violeta sirven para "hacer viva una lengua muerta", lo que tiene un aspecto cuasi religioso para ella y los demás integrantes de su colectivo. Según Andrea, homenajear a Violeta es "como decir un padre nuestro: 'Yo creo, venero, respeto su música, la comparto, la canto, la transmito a los pequeños". A pesar de ser atea, Morgado dice que participar en los homenajes a Violeta es como "rezarle a la virgen," quien es un ser vivo y a quien "se le agradece lo cotidiano, lo que da hoy" 34 En este sentido, Violeta sigue ofreciendo a sus adeptos "palabras cotidianas y vivas," de tal manera que la presencia de Violeta en las vidas de los participantes es "cotidiana y constante" y que los homenajes son como "una profesión de lealtad" y un intento de asegurar que no muera todo lo que Violeta representa en sus vidas y en su sociedad. ${ }^{35}$

Lucho González, del Trío Memorial, da otra razón de por qué homenajear a Violeta todos los años. Residente de la Población Ángela Davis en Recoleta, en la región metropolitana de Santiago, es folclorista, bailarín, declamador y fotógrafo, pero nunca ha vivido de su arte: lleva veinte años trabajando de taxista. Según Lucho, ella es "la mamita" de las y los folcloristas, trovadores y arpilleristas de Chile. Dice que, en el caso de todas las mamás, "las familias van a la tumba el día de su nacimiento y el día de su muerte". O sea, es una obligación ir al cementerio el 5 de febrero. Además, reconoce los tremendos talentos de Violeta, comentando que ella fue la primera latinoamericana en exponer su obra en el Louvre, preguntando "¿Quién más de aquí ha llegado ahí?”

Leoncio Faúndez, actual director musical de los Cantores que Reflexionan, santiaguino, profesor de música de un colegio, militante comunista y veterano de la resistencia contra la dictadura, recuerda la significancia que tuvieron los homenajes a los caídos en los que él había participado durante la dictadura. Cree que sucede algo similar con los homenajes a Violeta que ocurren en la actualidad. Según Faúndez y de acuerdo con sus experiencias como militante comunista, los rituales realizados por los miembros de la resistencia al régimen jugaron un papel imprescindible para mantener a los grupos cohesionados y con el espíritu en alto, sin importar si los actos fueran masivos o minúsculos. Leo piensa que los que participaron en la resistencia contra la dictadura "tienen esta cultura de ritual" que les habría mantenido cohesionados frente a la represión. Por eso dice, "actualmente a mucha gente siempre nos gusta salir a homenajear a Violeta ¡Y no somos el único grupo que lo hace!"’36

Maru Shultz, de la Agrupación Canto General, hace eco de este comentario de Leoncio cuando comenta los beneficios anímicos que tienen los homenajes a Violeta para la gente con conciencia social en estos días, un contexto en el que los luchadores sociales

\footnotetext{
${ }^{34}$ Entrevista con el autor en Santiago de Chile, 5 de marzo de 2016.

${ }^{35}$ Connerton (1989:59) nos llama a atender al formalismo en el lenguaje de los rituales, el cual tiene un efecto mnemónico para los grupos que los practican. En este sentido, podríamos pensar en la recitación de los versos de Violeta Parra como si fuera una especie de recitación de un credo que contribuyera al sostenimiento de la memoria colectiva de las y los participantes en los homenajes en su tumba. Además, como Jelín (2002:37) nos señala, los productos culturales -como las canciones- pueden servir de vehículos de la memoria. Nos remite también al premio Nobel norteamericano Bob Dylan, quien ha declarado que el léxico de su religión se encuentra en las canciones que canta.

${ }^{36}$ Entrevista con el autor en Santiago de Chile, 12 de marzo de 2016.
} 
están dispersos y enfrentan una situación política compleja y muchas veces poco alentadora. Maru hace hincapié en que los homenajes a Violeta reúnen a la gente "consecuente" y les recuerda que no está sola en su lucha a favor de una sociedad más justa. Al juntarnos, observa Maru, "nos revitalizamos, nos realimentamos" y "nos hace a nosotros sentirnos que no estamos solos en este mundo. ¡Que no estamos solos! Por eso es necesario para nosotros juntarnos." A esto su hermana Marcela agrega que el "despertar" a Violeta el día de su "fuga" nunca consistió exclusivamente en un acto de reverencia hacia ella, sino que también fue un intento de despertar su espíritu en los chilenos de su época. Richard Rojas le había dicho a Marcela hacía años que "al despertar a Violeta con nuestro canto los 5 de febrero despertamos la conciencia del pueblo." Y ahora Marcela sostiene que "por eso nosotros los 5 de febrero cantamos las injusticias, cantamos revolución, cantamos lo que hay que hacer. Por eso es tan importante esta fecha."

Teniendo en cuenta todo esto, podemos apreciar cómo la figura de Violeta Parra representa para los participantes en los homenajes un elemento primordial en su sentido de sí mismos en tanto miembros de una generación marcada por la lucha contra la dictadura y por una sociedad más justa. Si durante la dictadura los homenajes a Violeta servían, entre otras cosas, de pretexto para que los opositores al régimen se juntaran para hacer política, ahora en una nueva época política y cultural la figura de Violeta sigue aglutinando y esperanzando a las personas con memoria que aún creen en la defensa de "lo popular" en todas sus dimensiones. En este sentido, las canciones y décimas de Violeta Parra siguen siendo un elemento fundamental de la banda sonora de sus luchas políticas y personales. Asimismo, el ritual de juntarse a cantarlas frente a su tumba todos los años les recuerda quiénes son, cuáles han sido sus luchas, que no están solos y que siguen vivos, con el ánimo de seguir esforzándose para crear el tipo de mundo en el que quieren vivir. O sea que aún están y aún son consecuentes en sus convicciones. Y, aunque no sea una canción de Violeta, esto nos recuerda el refrán popular y el título de la vieja tonada que ella pudiera haber cantado en algún momento: Quien canta su mal espanta. ${ }^{37}$

La cantora Nora Blanco comenta que, para ella, los homenajes a Violeta Parra en los que ha participado durante años, sirven no solamente para rescatar la historia y preservar la memoria de Violeta y todo lo que ella representa, sino también para rescatar y comunicar a las nuevas generaciones las dolorosas experiencias de las personas que lucharon contra la dictadura desde dentro de Chile. Blanco insiste en que es necesario que "logremos traspasar todo esto, inclusive nuestras propias vivencias". Deben contar "la historia del tiempo de la dictadura que no está contada". Habla, por ejemplo, de las personas que quedaron exiliados en el interior, "con todo lo que significó la sobrevivencia, los dolores, el tener que pararte todos los días y decir 'Oye, ¿te contaron que mataron a tal compañero?' Lo lloraste y luego al otro día estabas otra vez de pie”. Aquí observamos que, al homenajear a la Violeta, los participantes en estos rituales no solamente hacen un esfuerzo por rescatar la memoria de ella y todo lo que simboliza sino también rinden honores a sí mismos, al menos implícitamente, e intentan comunicar la historia, de su

\footnotetext{
37 En realidad, la tonada "Quien canta su mal espanta" fue recolectada por la folclorista Margot Loyola, contemporánea y colega de Violeta Parra, y quien grabó el tema en su dúo Las Hermanas Loyola. Véase Ruiz Zamora (1995) y Loyola (2007).
} 
propia generación y todo lo que simboliza, a las nuevas generaciones que no experimentaron las vicisitudes de la resistencia a la dictadura. En este sentido, Nora resume las actitudes de muchos de los participantes en los homenajes, que creen que esto es, a fin de cuentas, una lucha contra el olvido: "Es necesario para nosotros juntarnos y unirnos, porque además hay mucha gente que, por diferentes razones, se ha olvidado de todo esto. Como que no quieren recordar absolutamente nada de lo vivido." 38

Concluyendo este recuento de la historia y la práctica de los homenajes populares a Violeta Parra en su tumba los 5 de febrero, deberíamos resaltar que ésta es una práctica y un proyecto no solamente cultural sino eminentemente social y comunitario. No es accidente, pues, que las personas que han llevado a cabo los homenajes a Violeta durante el pasado medio siglo -por espontáneos e informales que hayan sido- lo hayan hecho de manera organizada y colectiva. De hecho, este proyecto, desde su inicio, ha sido realizado a través de colectivos consensuales y compuestos por personas que sienten la necesidad de hacer algo en conjunto para hacer memoria, expresar y reafirmar sus identidades compartidas, sanar sus heridas y recuperar fuerzas para poder enfrentar los nuevos retos culturales y políticos que la historia chilena les ha legado. Si bien la figura de Violeta Parra sirvió de pretexto para organizar actos de resistencia al régimen durante la dictadura, los colectivos que realizan los homenajes a ella en la actualidad aprovechan su figura icónica para construir nuevas comunidades de conciencia que reafirmen los valores de antaño que ella representa. Mauricio Gutiérrez, el convocador de los Cantores que Reflexionan, soñó con hacer comunidad en base a las canciones de Violeta (y también de Víctor) en estos mismos términos, comentando, "qué lindo sería juntar toda esta gente que viene de diferentes comunas, de diferentes edades, no todos son músicos pero lo que nos une es el canto de la Violeta o el canto de Víctor y puedes tocar la guitarra y simplemente en esos cuatro minutos que dura una canción, poder tener una comunión que pudiera unirnos y poder transmitirla así y amplificarla". Observó lo que otros entrevistados también habían comentado, que parecía haber un hambre de comunidad en Chile y que brotaban colectivos "anti-sistémicos" en varias esferas de la sociedad, no solamente en las artes, que operaban sin el dinero de por medio y que emergían "de manera orgánica" de acuerdo con los intereses, valores y aspiraciones de sus participantes. En el caso de los colectivos discutidos en estas páginas, han encontrado en Violeta Parra una inspiración y un sostén imprescindibles.

\section{Bibliografía}

Agosín, Marjorie e Inés Dolz-Blackburn. 1988. Violeta Parra: Santa de pura greda. Santiago de Chile: Planeta.

Alegría, Fernando. 1954. La poesía chilena: Orígenes y desarrollo del siglo XVI al XIX. México, DF: Fondo de Cultura Económica.

Arguedas, José María. 1968 "Análisis de un genio popular: Violeta Parra". Revista de Educación (Universidad Católica, Santiago de Chile) 13:66-76.

\footnotetext{
${ }^{38}$ Véase Arias y del Campo, 2009:8 sobre "el modelo cultural del olvido" de los gobiernos de la Concertación en el período pos-dictadura en Chile.
} 
Arias, Arturo y Alicia del Campo. 2009. "Introduction: Memory and Popular Culture." Latin American Perspectives 36:5:3-20.

Barros, Raquel y Manuel Dannemann. 1958. "La poesía folklórica en Melipilla." Revista Musical Chilena 12:60:48-70.

Berman, Marshall. 1983. All That Is Solid Melts into Air: The Experience of Modernity. New York: Simon \& Schuster.

Connerton, Paul. 1989. How Societies Remember. Cambridge, Reino Unido: Cambridge University Press.

Contreras Román, Raúl H. 2016. "Margot Loyola y Violeta Parra en el encuentro de la izquierda y la música folclórica en Chile. Cuicuilco 66:192-221.

Corvalán, Luis. 1997. De lo vivido y lo peleado: Memorias. Santiago de Chile: LOM Ediciones.

Díaz-Inostroza, Patricia. 2007. El Canto Nuevo Chileno: Un legado musical. Santiago de Chile: Editorial Universidad Bolivariana.

Diemert, Brian. 2011. "Time and Timelessness: Contexts for Popular Music." Páginas 12 a 35 en Resounding Pasts; Essays in Literature, Popular Music, and Cultural Memory, coordinado por Drago Momcilovic. Cambridge, Reino Unido: Cambridge Scholars Publishing.

Dolz-Blackburn, Inés. 1984. Origen y desarrollo de la poesía tradicional y popular chilena desde la conquista hasta el presente. Santiago de Chile: Editorial Nascimento.

Drake, Paul. 1993. "Chile 1930-1958." Páginas 87-128 en Chile Since Independence, coordinada por Leslie Bethell. Cambridge, Reino Unido: Cambridge University Press.

Durkheim, Emile. 1971. The Elementary Forms of the Religious Life. London: Allen and Unwin.

Edmunds, June y Bryan S. Turner. 2002. "Generational Consciousness, Narrative, and Politics." Páginas 1 a 12 en Generational Consciousness, Narrative, and Politics, coordinado por June Edmunds and Bryan S. Turner. Lanham, Maryland EEUU: Roman \& Littlefield.

Epple, Juan Armando. 1977. "Violeta Parra y la cultura popular chilena." Literatura chilena en el exilio 1:2:4-11.

Errl, Astrid. 2008. "Cultural Memory Studies: An Introduction.” En Cultural Memory Studies: An International and Interdisciplinary Handbook (libro electrónico). Astrid Erll y Ansgar Nünning, coordinadores. Nueva York: Walter de Gruyter.

Eyerman, Ron. 2002. "Music in Movement: Cultural Politics and Old and New Social Movements." Qualitative Sociology 25:3:443-458.

Eyerman, Ron y Bryan S. Turner. 1998. "Outline of a Theory of Generations." European Journal of Social Theory 1:1:91-106.

Galeano, Eduardo. 2002. Memoria de fuego, Tomo 3: El siglo del viento. México, D.F.: Siglo XXI.

García Méndez, José Andres. 2016. "Música y antropología. Notas acerca de una relación olvidada." Cuicuilco 66:11-23.

Godoy, Álvaro y Juan Pablo González. 1995. Música popular chilena: 20 años: 1970 a 1990. Santiago de Chile: División de Cultura del Ministerio de Educación.

González, Juan Pablo. 2016. "Nueva Canción Chilena en dictadura: Divergencia, memoria, escuela (1973-1983).” Estudios Interdisciplinarios de América Latina y el Caribe 27:1:63-82.

González, Juan Pablo, Oscar Ohlsen y Claudio Rolle. 2009. Historia social de la música popular en Chile, 1950-1970. Santiago de Chile: Ediciones Universidad Católica de Chile.

González Farfán, Cristián y Gabriela Bravo Chiapp. 2009. Ecos del tiempo subterráneo: Las peñas en Santiago durante el régimen militar (1973-1983). Santiago de Chile: LOM Ediciones.

Halbwachs Maurice. 1992. On Collective Memory. Traducido por Lewis A. Coser. Chicago, Illinois: University of Chicago Press.

Heinich, Natalie. 2010. "La falsificación como reveladora de la autenticidad." Revista de Occidente Número 345, febrero. Descargado el 6 de enero de 2018 de 
http://www.revistasculturales.com/articulos/97/revista-de-occidente/1243/1/la-falsificacioncomo-reveladora-de-la-autenticidad.html.

Hobsbawm, Eric. 1983. "Introduction: Inventing Traditions." Páginas 1 a 14 en The Invention of Tradition, coordinado por Eric Hobsbawm y Terence Ranger. Cambridge, Reino Unido: Cambridge University Press.

Jordán, Laura. 2009. "Música y clandestinidad en dictadura: la represión, la circulación de músicas de resistencia y el casete clandestino," Revista Musical Chilena 212:77-102.

Longa, Francisco. 2017. "¿Existen las generaciones políticas? Reflexiones en torno a una controversia conceptual." Íconos: Revista de Ciencias Sociales 58:205-224.

Loveman, Brian. 1979. Chile: The Legacy of Hispanic Capitalism. Oxford, Reino Unido: Oxford University Press.

Loyola, Margot. 2007. La tonada: Testimonios para el futuro. Valparaíso, Chile: Ediciones Universitarias de Valparaíso.

Marín, Gladys. 2009. "Testimonio de Gladys Marín.” Páginas 133-134 en El libro mayor de Violeta Parra: Un relato biográfico y testimonial, compilado por Isabel Parra. Santiago de Chile: Editorial Cuarto Propio.

Morales, Leonidas. 2003. Violeta Parra: La última canción. Santiago de Chile: Editorial Cuarto Propio.

McSherry, J. Patrice. 2017. La nueva canción chilena. El poder político de la música, 1960-1973. Santiago de Chile: LOM Ediciones.

Miranda Herrera, Paula. 2014. La poesía de Violeta Parra. Santiago de Chile: Editorial Cuarto Propio.

Morales T., Leonidas. 2003. Violeta Parra: La última canción. Santiago: Cuarto Propio.

Monsiváis, Carlos. 2008. "Frida Kahlo: De las etapas de su reconocimiento". Debate Feminista 19:37: 3-15 (cuerpos sufrientes).

Montecino, Sonia. 2017. "Runrunes y Albertíos/Madres y jardineras: Apuntes para una lectura de los imaginarios de género en algunos escritos de Violeta Parra." Páginas 49 a 74 en Violeta Parra: Después de vivir un siglo, coordinado por Claudia Guzmán Mattos. Santiago de Chile: Consejo Nacional de la Cultura y las Artes.

Moulian, Tomás. 1997. Chile: Anatomía de un mito. Santiago de Chile: LOM Ediciones.

Moulian, Tomás. 1998. El consumo me consume. Santiago de Chile: LOM Ediciones.

Movimiento Generación 80. 2007. "Quienes somos." Descargado el 3 de agosto de 2017 de http://www.generacion80.cl/quienessomos.htm.

Nugin, Raili. 2010. "Social Time as the Basis of Generational Consciousness." TRAMES A Journal of the Humanities and Social Sciences 14:4:342-366.

La Nación. 1969. "Hoy rinden homenaje a Violeta Parra." p. 16.

Nuevo Mundo Patagonia. 2017. "Después de vivir un siglo: 100 años de Violeta Parra." Radio Nuevo Mundo, 5 de febrero. Descargado el 18 de julio de 2017 de http://www.nuevomundopatagonia.cl/web/2017/02/05/despues-de-vivir-un-siglo-100-anosde-violeta-parra/.

Olick, Jeffrey K. 2008. "From Collective Memory to the Sociology of Mnemonic Practices and Products." En Cultural Memory Studies: An International and Interdisciplinary Handbook (libro electrónico). Astrid Erll y Ansgar Nünning, coordinadores. Nueva York: Walter de Gruyter.

Olick, Jeffrey K. and Joyce Robbins. 1998. "Social Memory Studies: From 'Collective Memory' to the Historical Knowlede of Mnemomic Practices.” Annual Review of Sociology. 24:105140. 
Palominos, Simón. 2017. "Una hipótesis para historizar la obra de Violeta Parra: El rol del folclor en el desarrollo del campo cultural durante el estado de compromiso." Pp. 238-243 en Violeta Parra: Después de vivir un siglo, coordinado por Claudia Guzmán Mattos. Santiago de Chile: Consejo Nacional de la Cultura y las Artes.

Parra, Isabel. 2009. El libro mayor de Violeta Parra: Un relato biográfico y testimonial, $2^{a}$ edición. Santiago de Chile: Editorial Cuarto Propio.

Parra, Violeta. 1998. Décimas: Autobiografía en verso. Santiago de Chile: Editorial Sudamericana. Pinochet Cobos, Carla. 2010. "Violeta Parra: tensiones y transgresiones de una mujer popular de mediados del siglo XX." Revista Musical Chilena 213:77-89.

Prieto, Genaro, Alejandro Masmar y Jorge Calvo. 2013. Todavía cantamos: Historia de un canto valiente... Aymará y sus amigos. Santiago de Chile: Signo Editorial.

Rector, John L. 2003. The History of Chile. Westport, Connecticut, EEUU: Greenwood Press.

Ríos, Fernando. 2008. "La Flûte Indienne: The Early History of Andean Folkloric-Popular Music in France and Its Impact on Nueva Canción." Latin American Music Review 29:2:145-189.

Rodríguez, Osvaldo. 2015. Cantores que reflexionan: Notas para una historia personal de la Nueva Canción Chilena. Santiago de Chile: Hueders.

Rosenthal, Robert y Richard Flacks. 2011. Playing for Change: Music and Musicians in the Service of Social Movements. Boulder: Paradigm Publishers.

Ruiz Zamora, Agustín. 1995. "Discografía de Margot Loyola." Revista Musical Chilena No. 183: 42-58.

Sáez, Fernando. 2012. Violeta Parra: La vida intranquila: Biografía esencial, segunda edición. Santiago de Chile: LOM Ediciones.

Schuman, Howard y Jacqueline Scott. 1989. "Generations and Collective Memories.” American Sociological Review 54:359-381.

Soublette, Gastón. 2017. "Violeta, profetisa de nuestra tierra." Páginas 219 a 229 en Violeta Parra: Después de vivir un siglo, coordinado por Claudia Guzmán Mattos. Santiago de Chile: Consejo Nacional de la Cultura y las Artes.

Subercaseaux, Bernardo. 2017. "Violeta Parra: Una vida y una trayectoria." Páginas 21 a 44 en Violeta Parra: Después de vivir un siglo, coordinado por Claudia Guzmán Mattos. Santiago de Chile: Consejo Nacional de la Cultura y las Artes.

Spener, David. 2015. "Between Nostalgia and Sustained Commitment: Music and Memory in the Lives of Chilean Luchadores Sociales" Trabajo presentado en San Juan, Puerto Rico el 27 de mayo en el XXXIII Congreso Internacional de la Latin American Studies Association.

Spener, David. 2017. No nos moverán: Biografía de una canción de lucha. Santiago de Chile: LOM Ediciones.

Štambuk, Patricia y Patricia Bravo. 2011. Violeta Parra: El canto de todos. Santiago de Chile: Pehuén.

Torres Alvarado, Rodrigo. 2004."Cantar la diferencia: Violeta Parra y la canción chilena." Revista Musical Chilena 201:53-73.

Verba, Ericka Kim. 2013. "To Paris and Back: Violeta Parra's Transnational Performance of Authenticity." The Americas 70:2:269-302.

Verba, Ericka Kim. 2007. "Violeta Parra, Radio Chilena, and the 'Battle in Defense of the Authentic' During the 1950s in Chile." Studies in Latin American Popular Culture 26:151165.

Zarzycka, Marta. 2006. "Now I Live on a Painful Planet': Frida Kahlo Revisited." Third Text 20:1:73-84. 
Figuras y fotografías

Fotografías series 6a-f y 7a-f. Homenaje de la Agrupación Canto General, 5 de febrero 2011

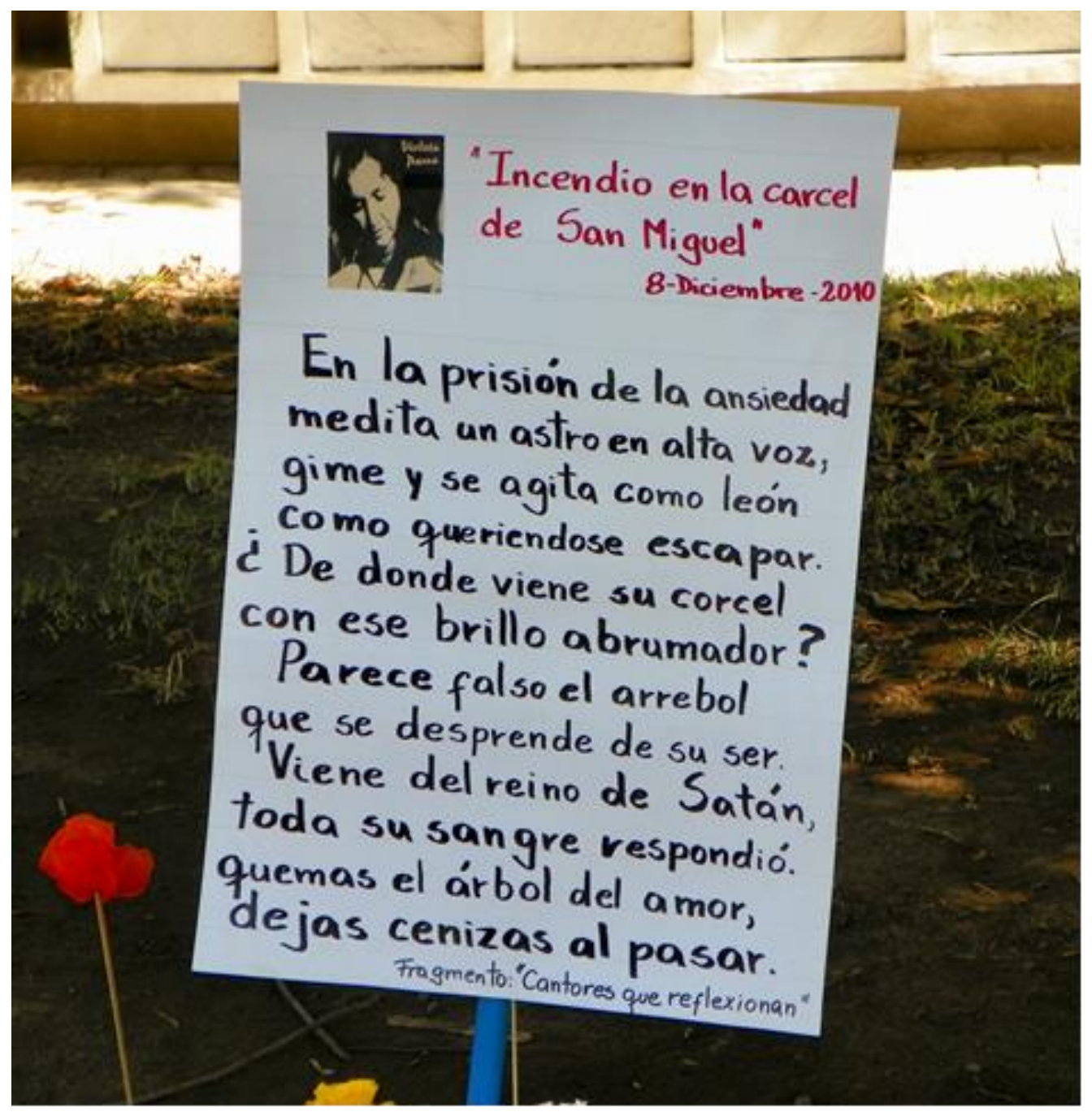

Fotografía 6-a 


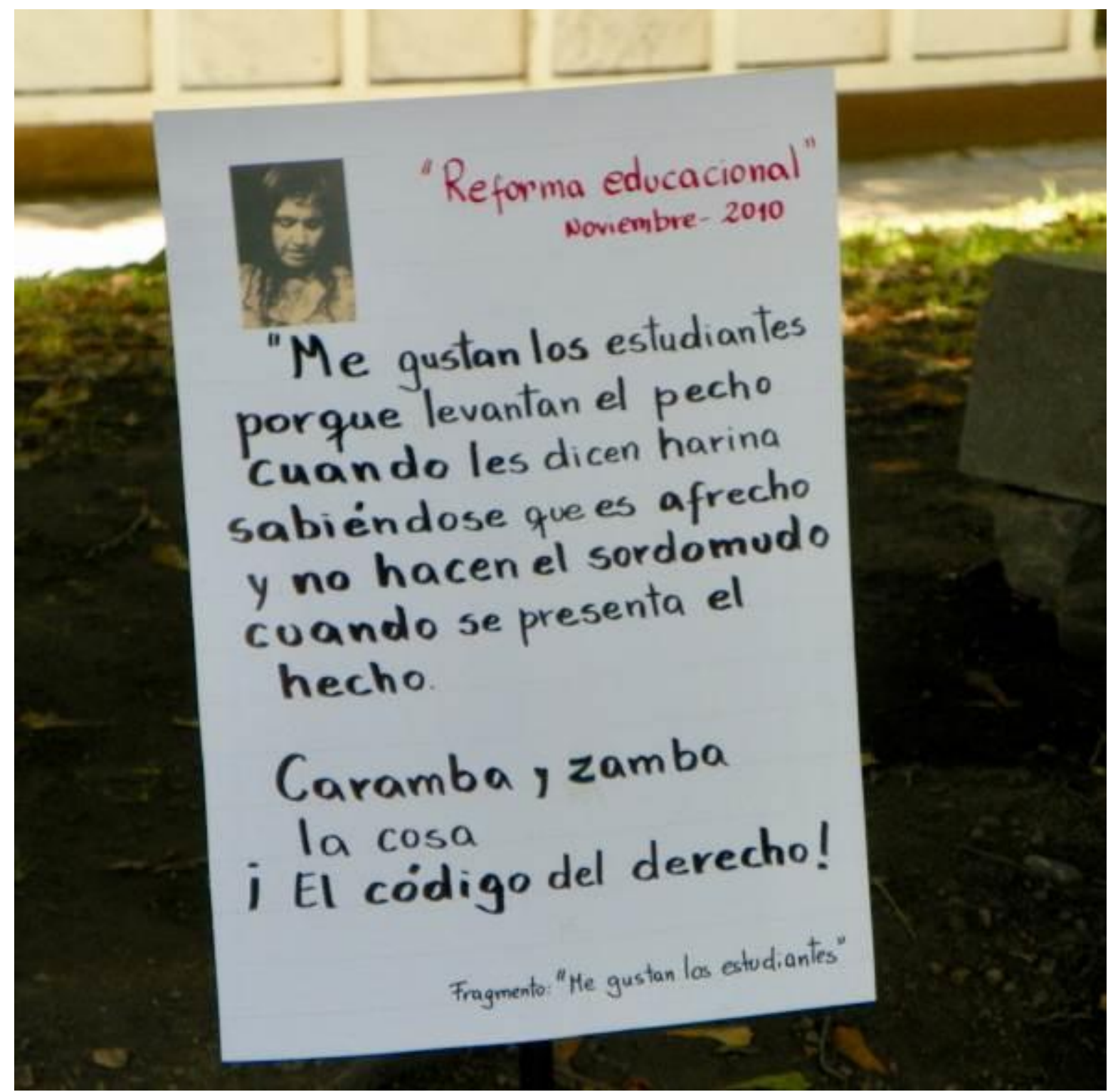

Fotografía 6-b 


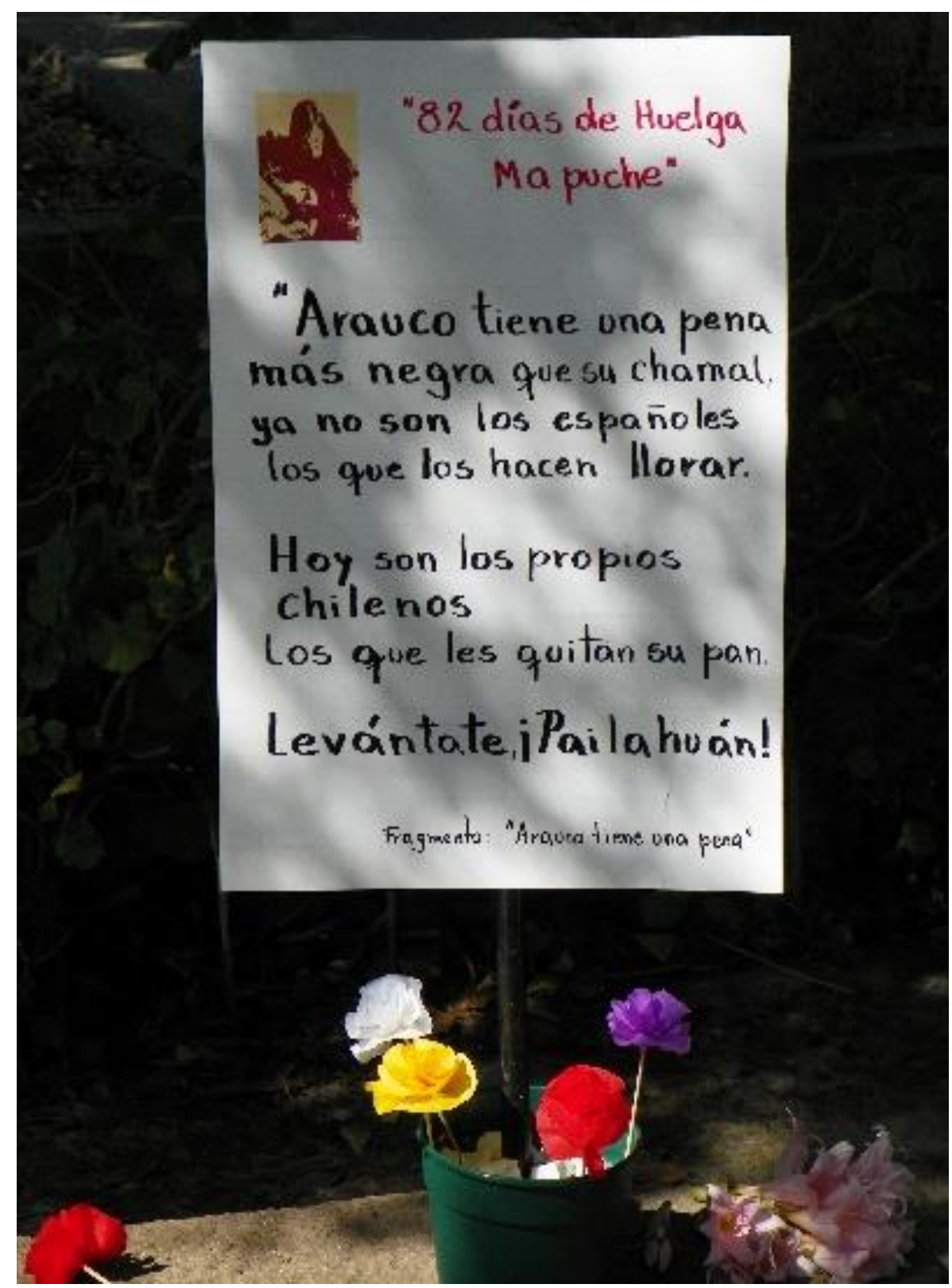

Fotografía 6-c 


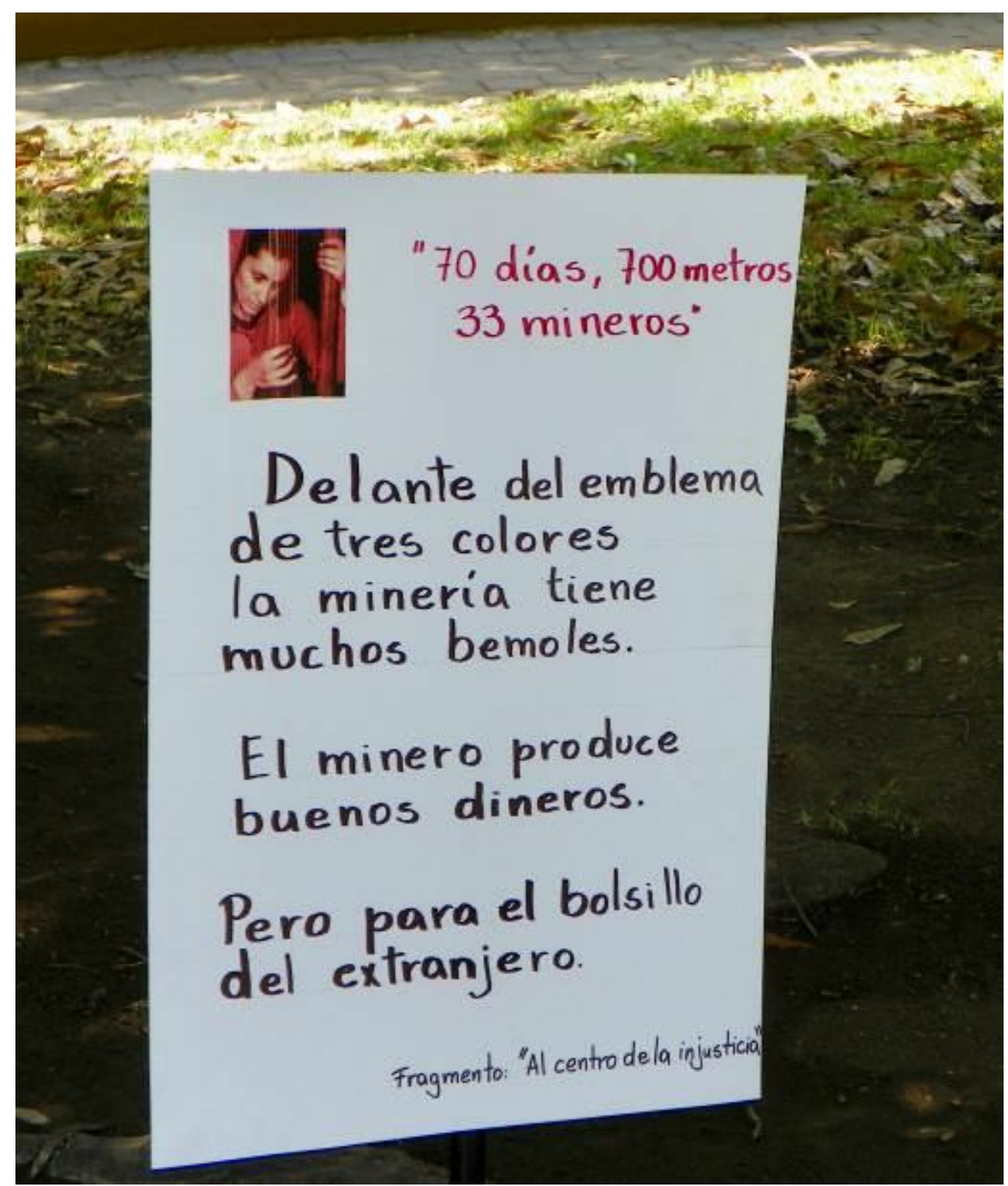

Fotografía 6-d 


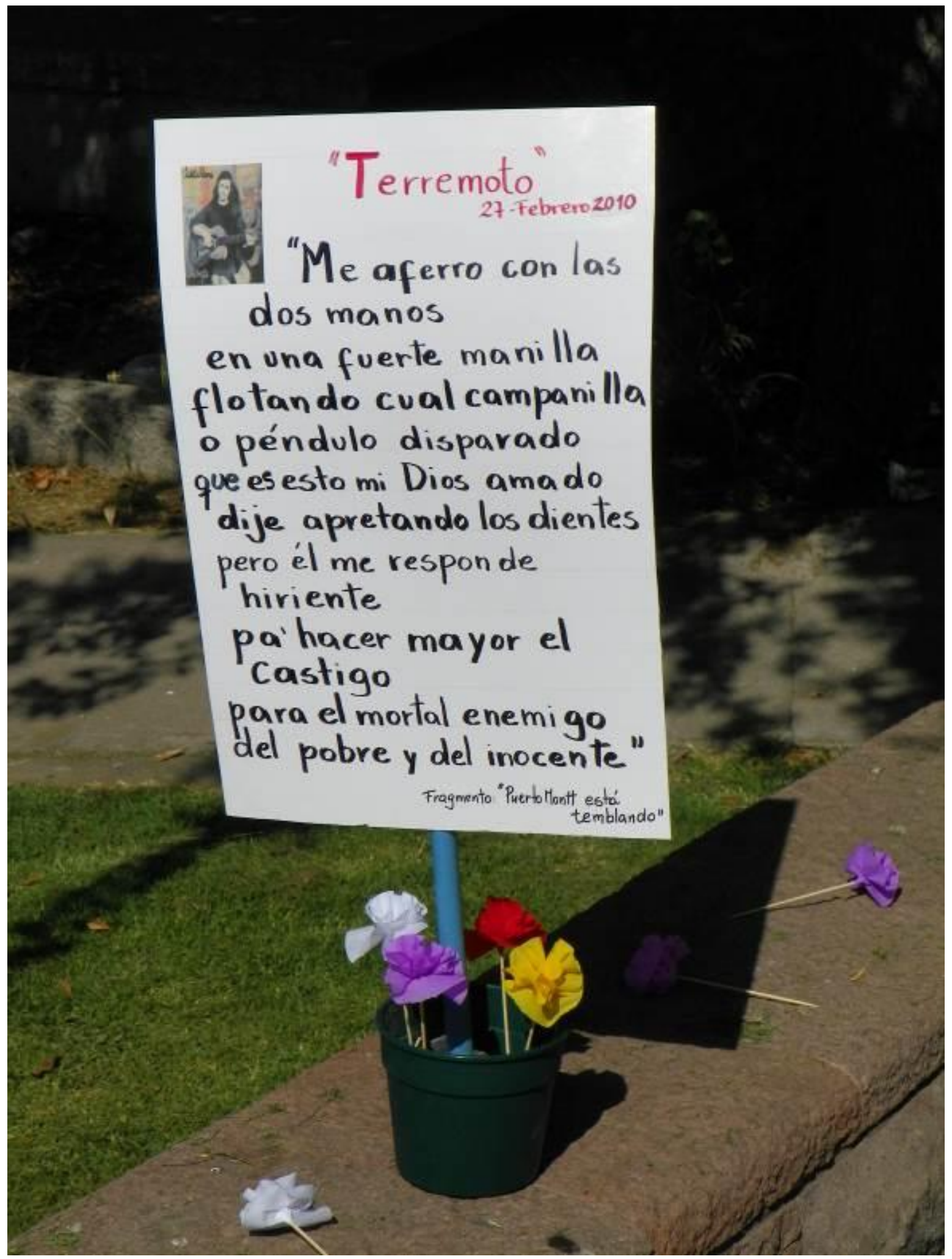

Fotografía 6-e 


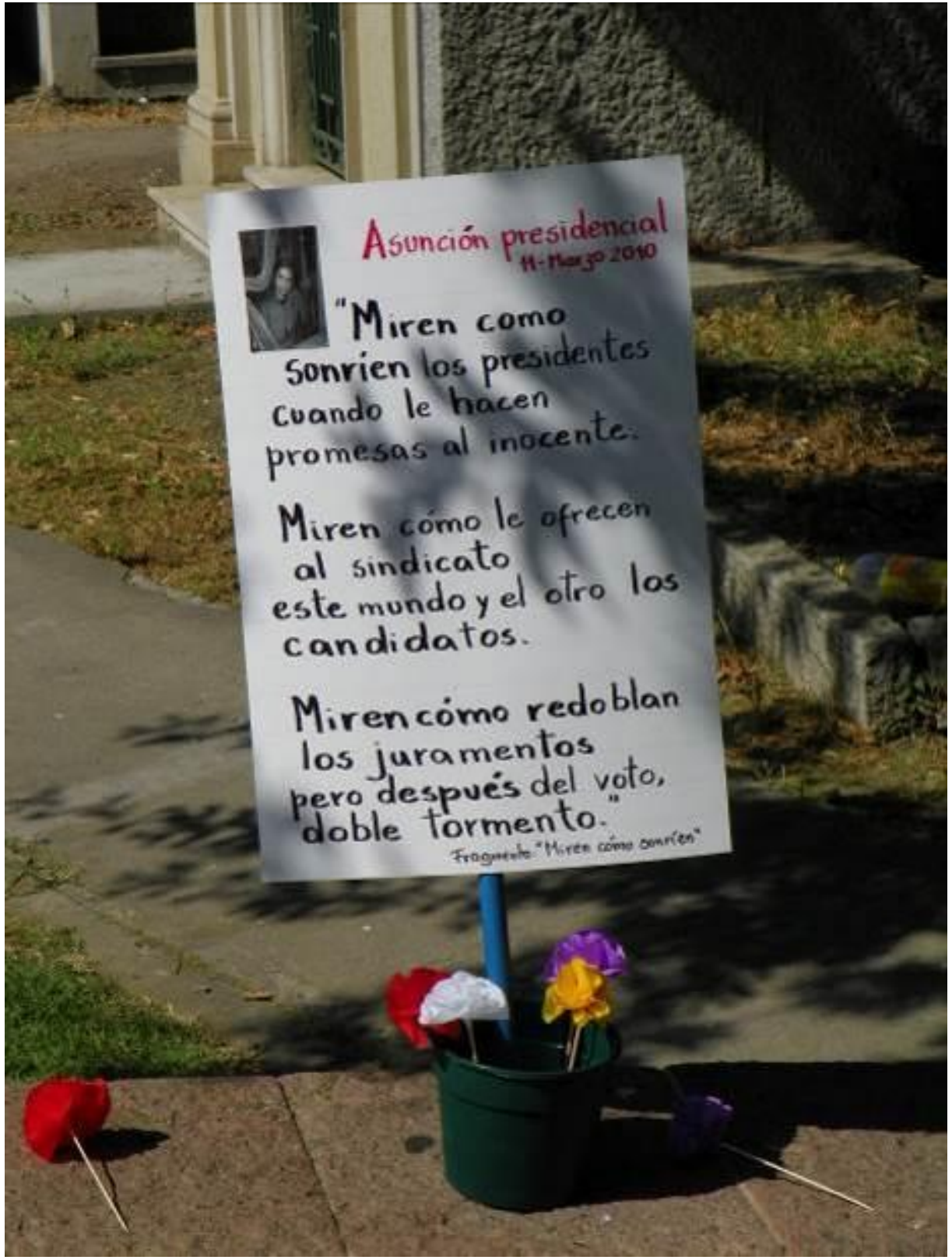

Fotografía $6 f$ 
Fotografías serie 7a-f. Homenaje de la Agrupación Canto General, 5 de febrero 2011

7a-e tomadas por el autor; 7f de la colección de María Isabel Shultz

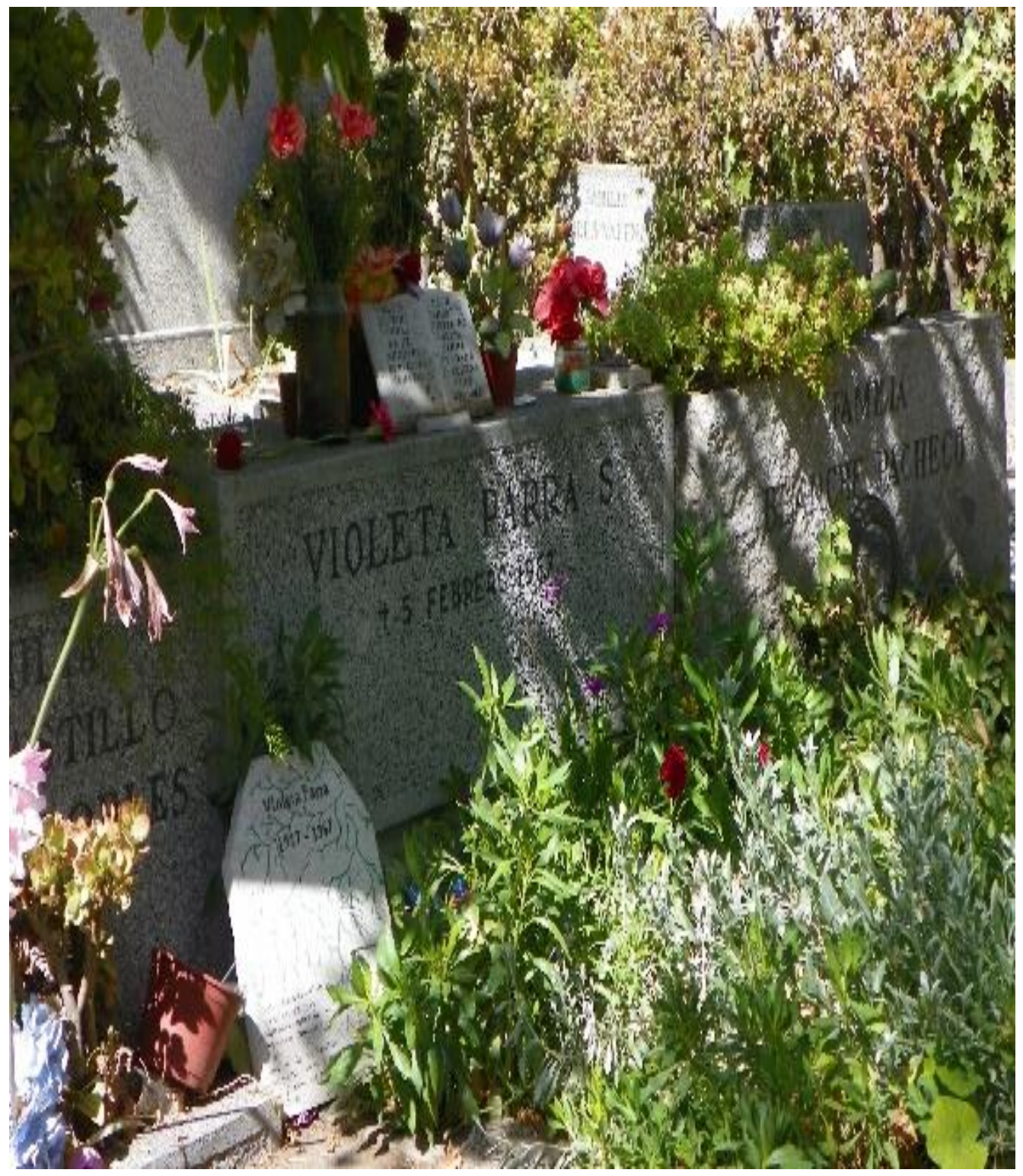

7a. Tumba de Violeta Parra 


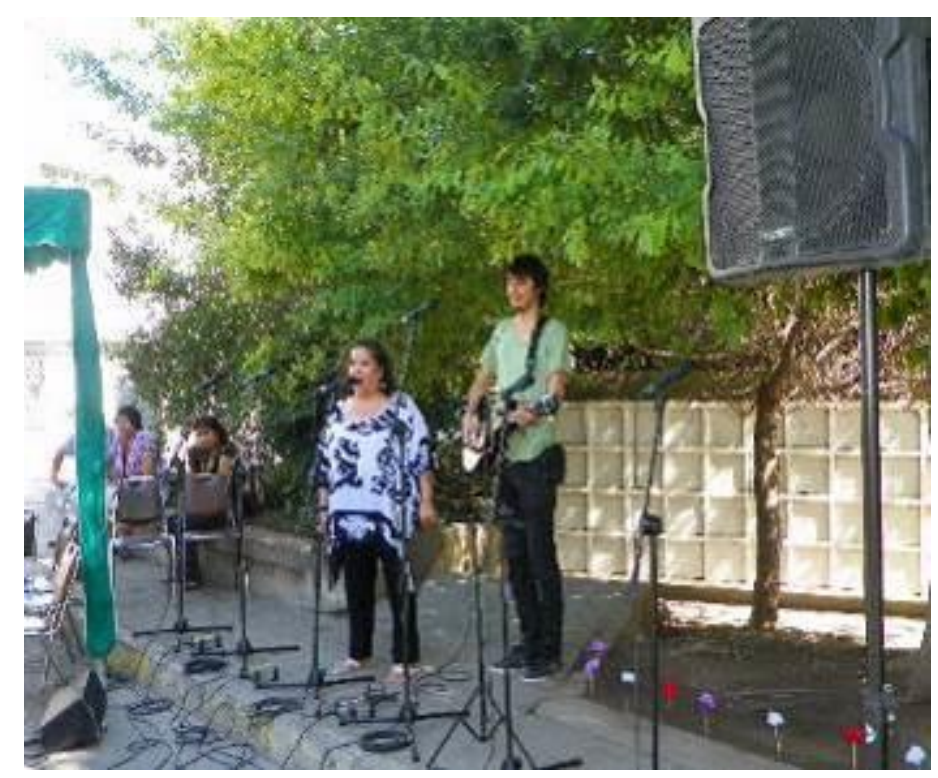

7b. Nora Blanco con joven guitarrista

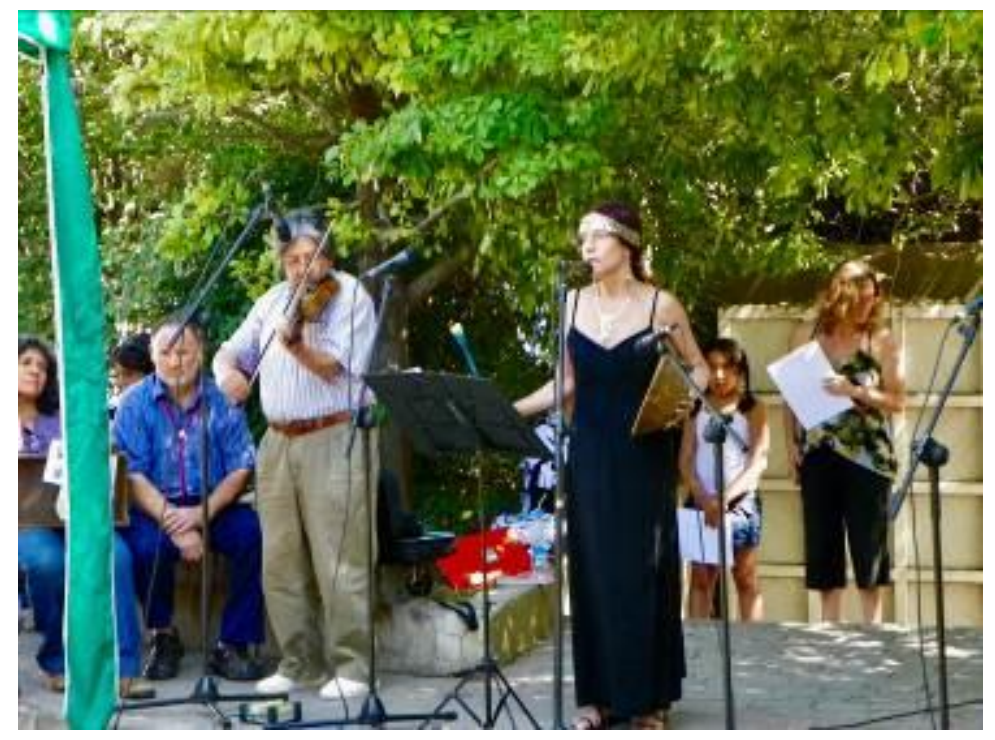

7c. Rebeca Garrido recita "Arauco tiene una pena" 


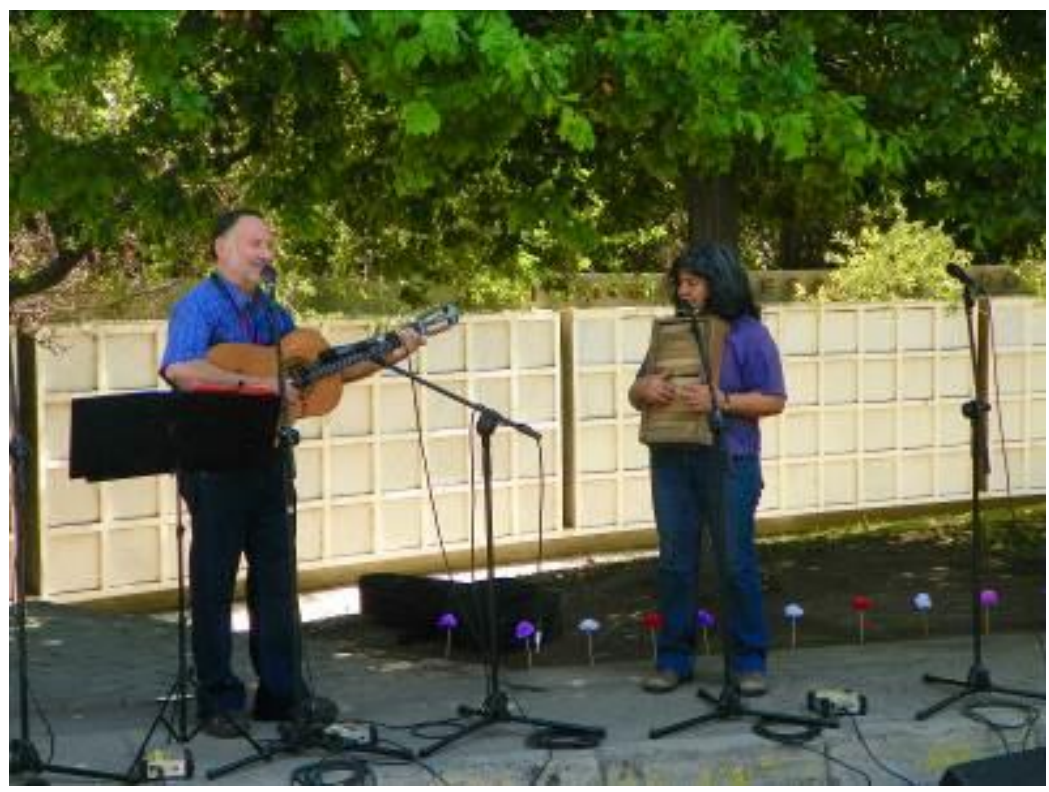

7d. Cantan Pelusa Rayen y Tito Ulloa

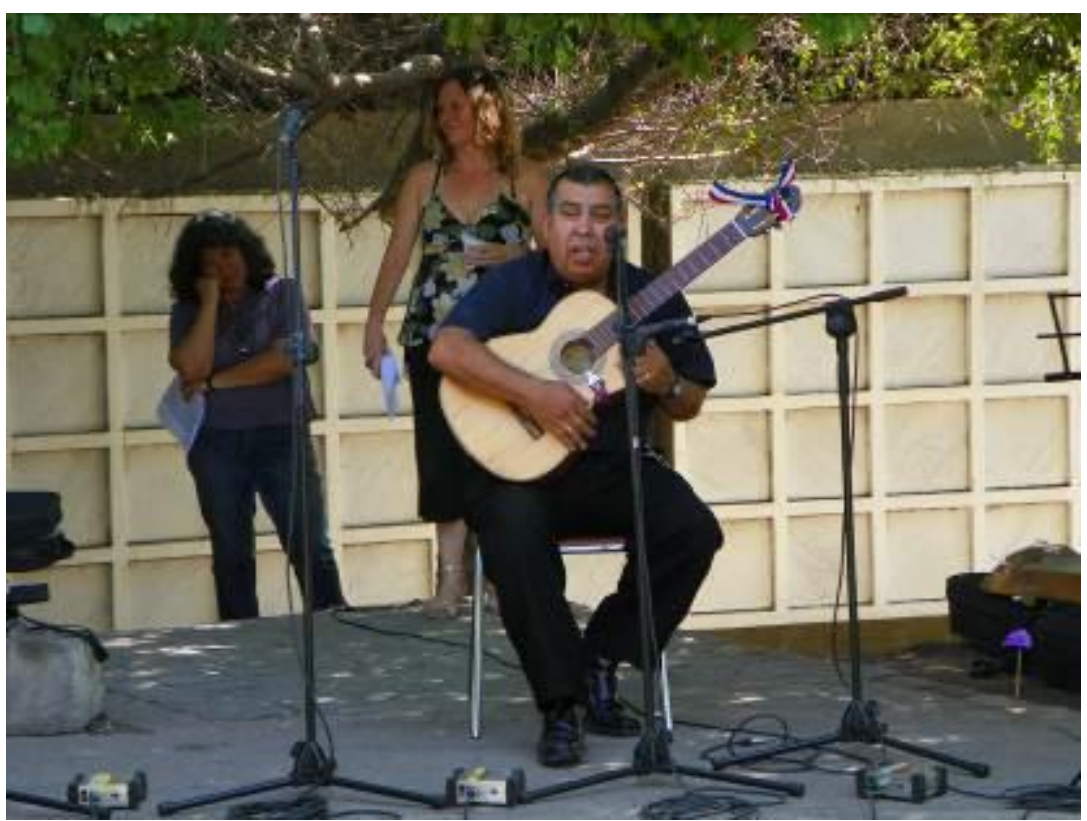

7e. Canta folclorista desconocido, Marcela Shultz y Pelusa Rayen observan desde detrás del escenario 


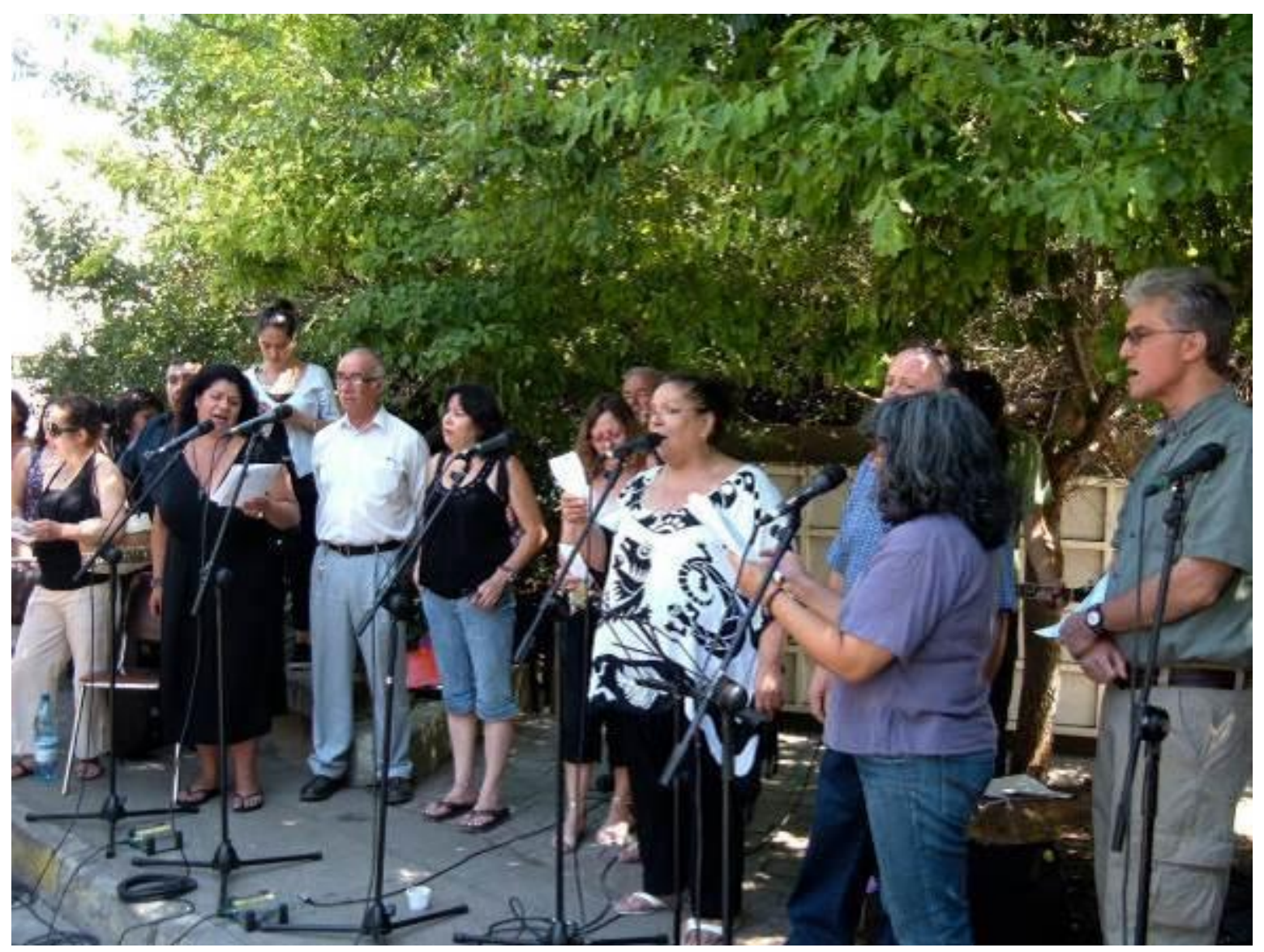

7f. Cantores y público cantan "Gracias a la vida" 
Figura 1. Ficha repartida por Mauricio Gutiérrez en Mil Guitarras para Víctor Jara 2014

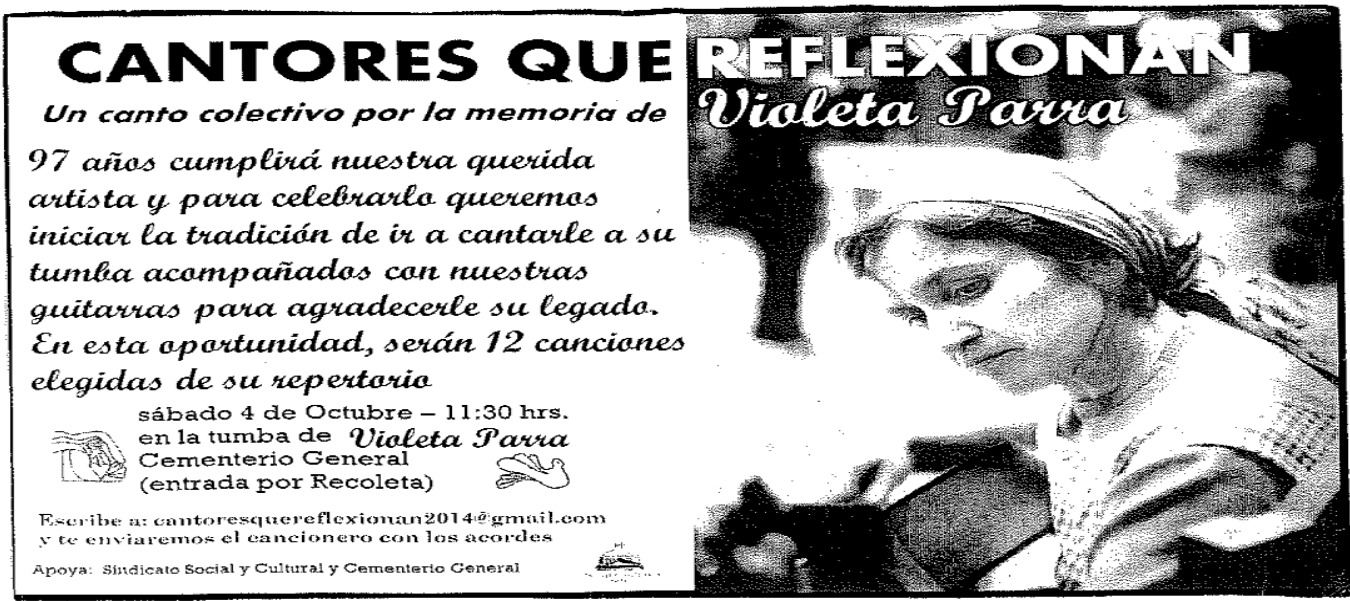


Figura 2 Invitación al homenaje de la Agrupación Canto General del 5 de febrero de 2016

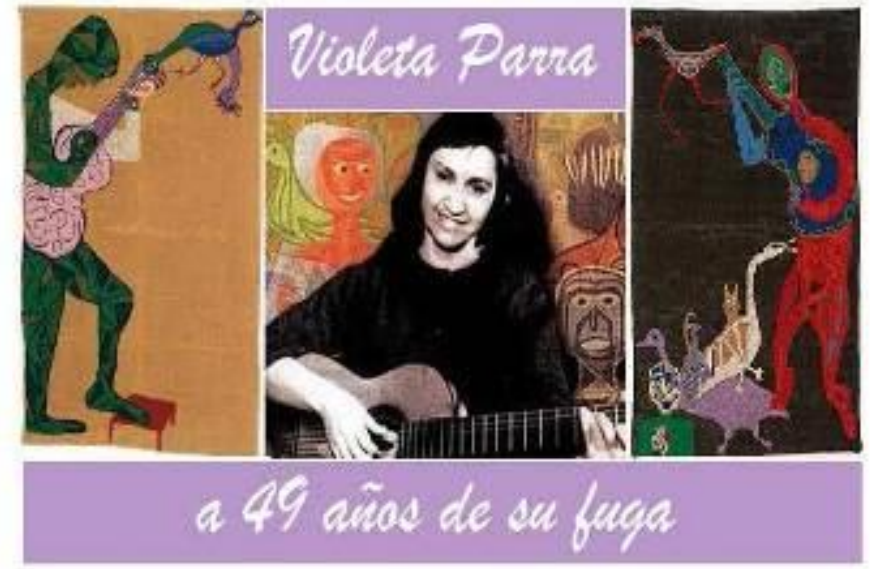

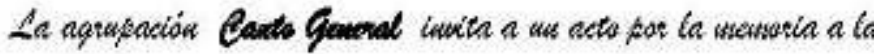

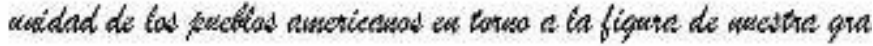
Viatem Pena.

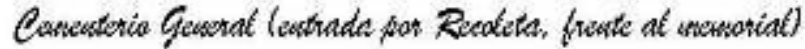
Vieroed 5 de febreto 2076 - 11:00 horas

Confinurada en particleaciou de:

Nona Banes - Manio Lorea - Dradd Spewen - Manda Shulty

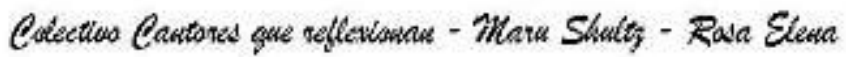

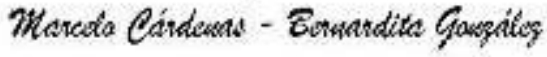

Figura 3. Invitación al homenaje organizado por Trío Memorial, 6 de febrero de 2016

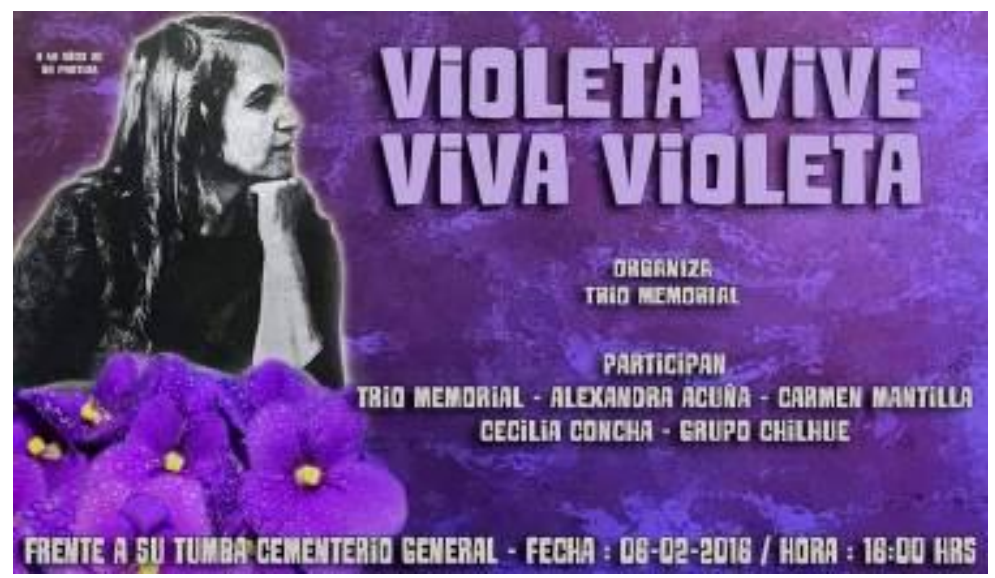


Fotografías serie 8a-f. Homenaje de la Agrupación Canto General con Los Cantores que Reflexionan, 5 de febrero de 2016

Fotografías tomadas por el autor

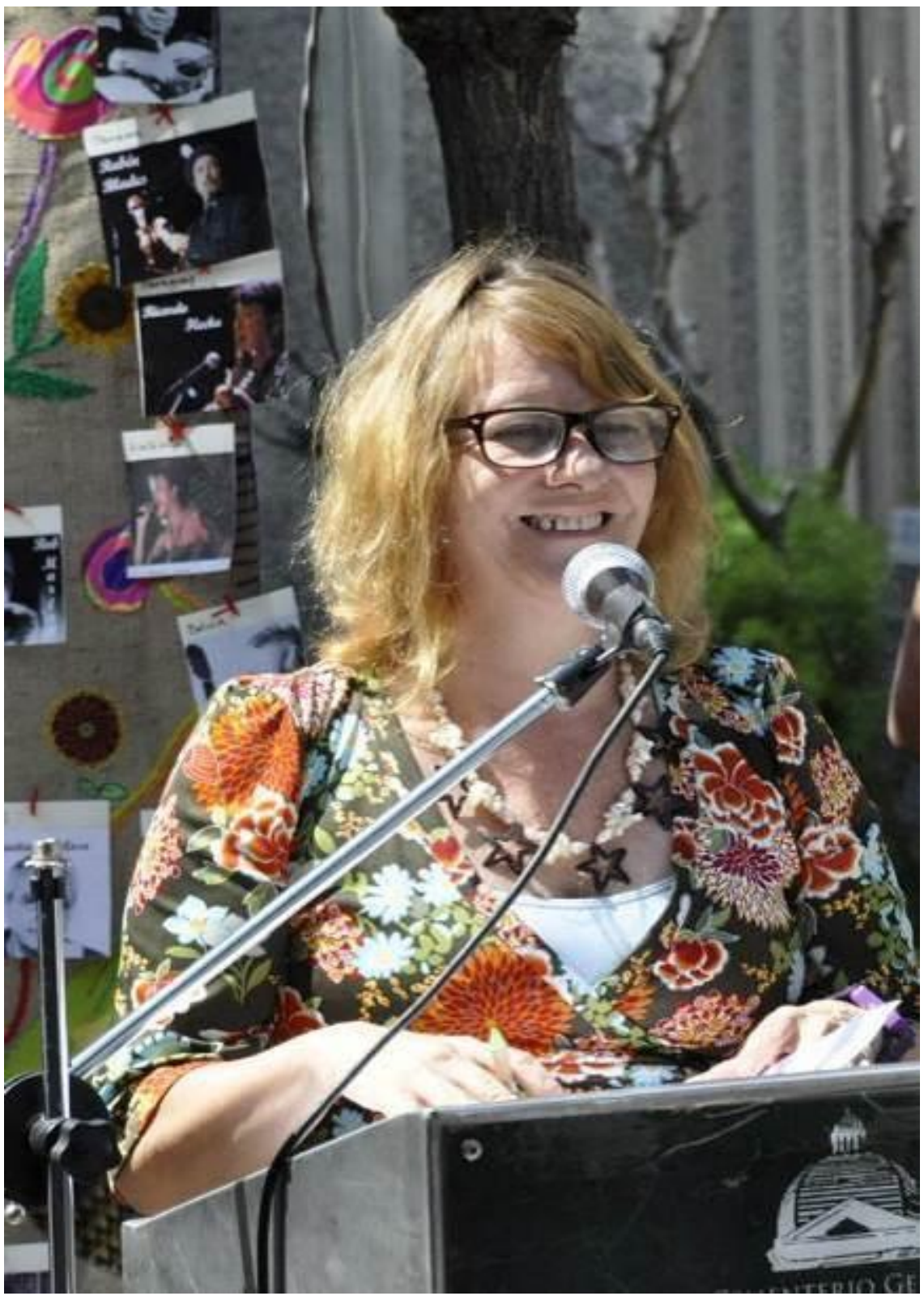

8a. Marcela Shultz dando la bienvenida 


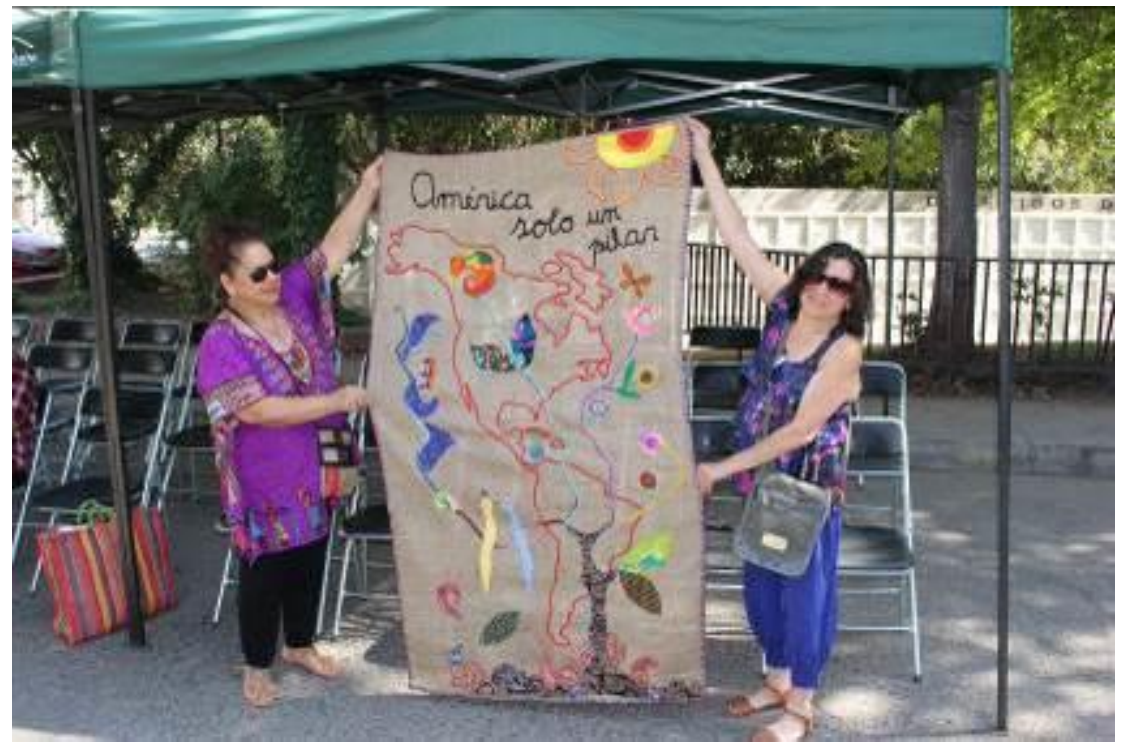

8b. Nora Blanco y Maru Shultz enseñando arpillera "América, solo un pilar"

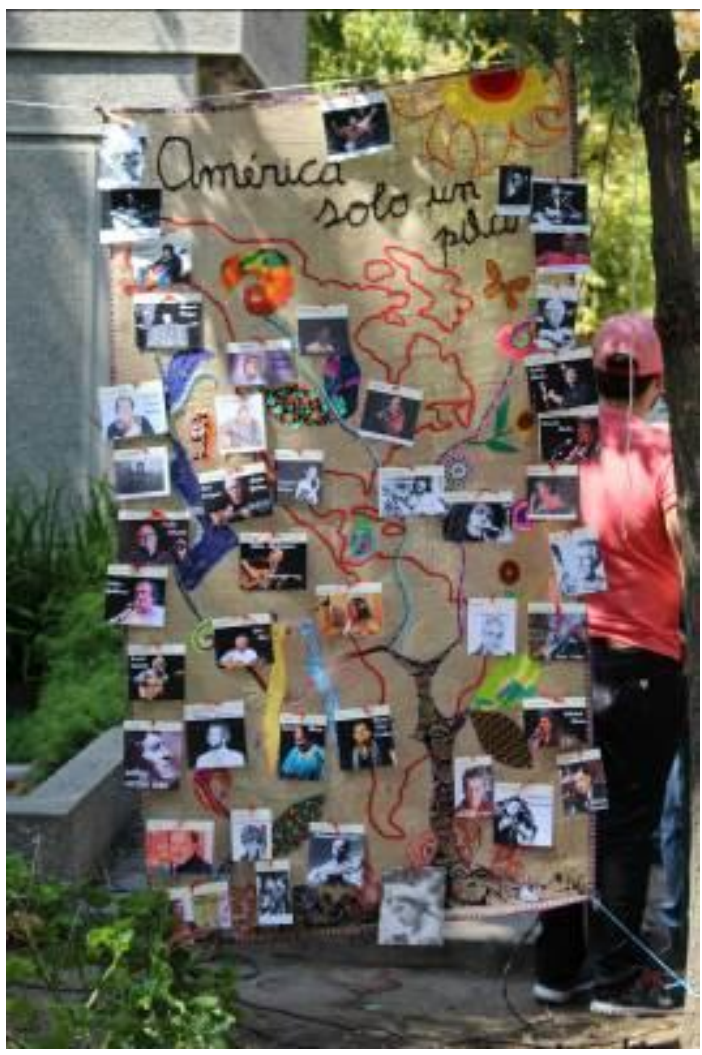




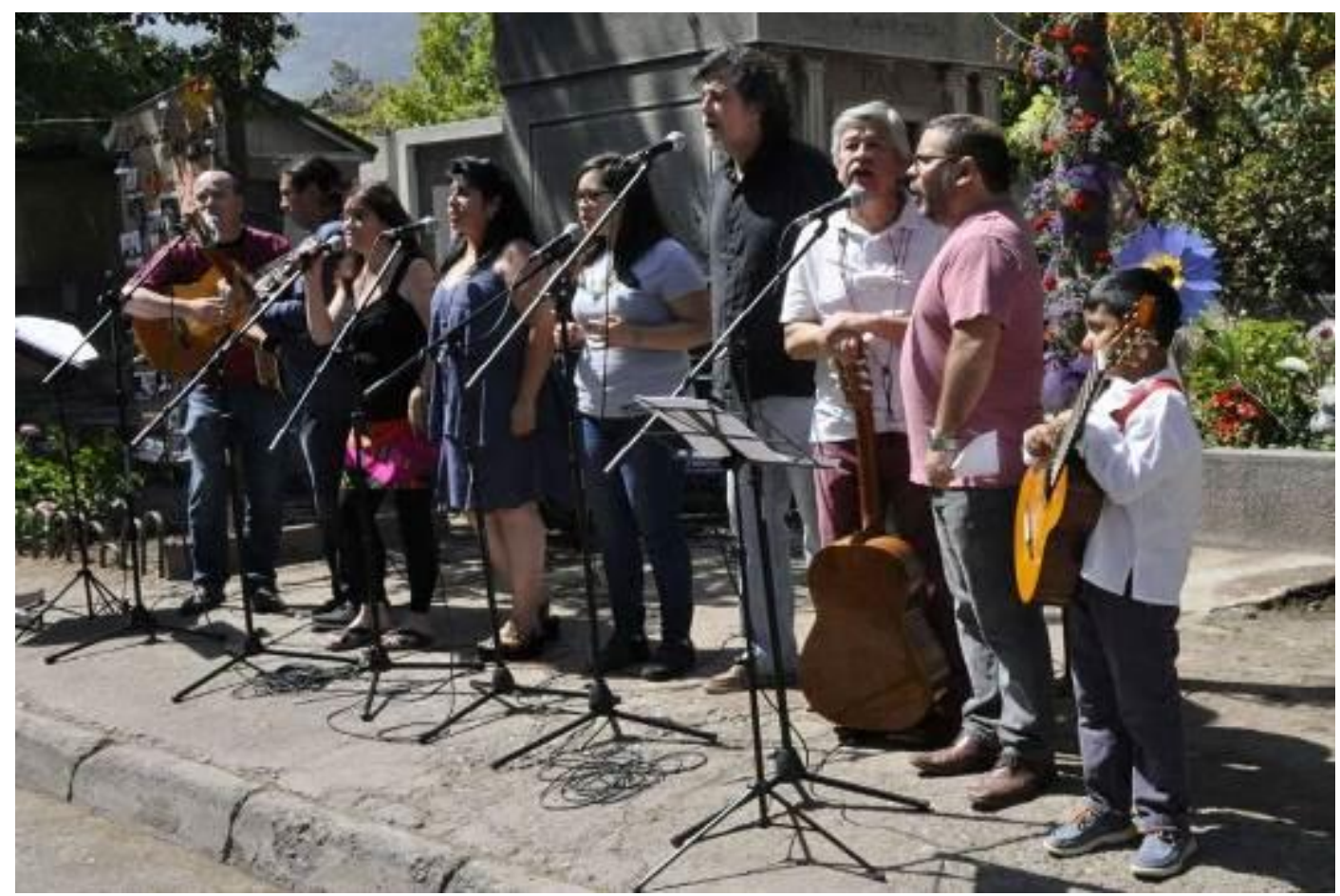

8d. Los Cantores que Reflexionan

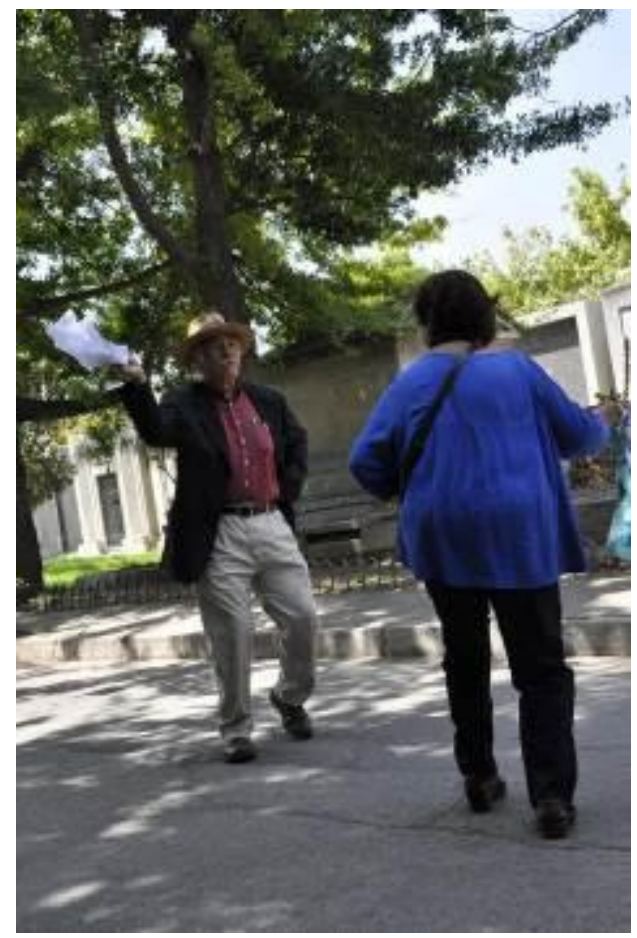

8e. Bailando cueca 


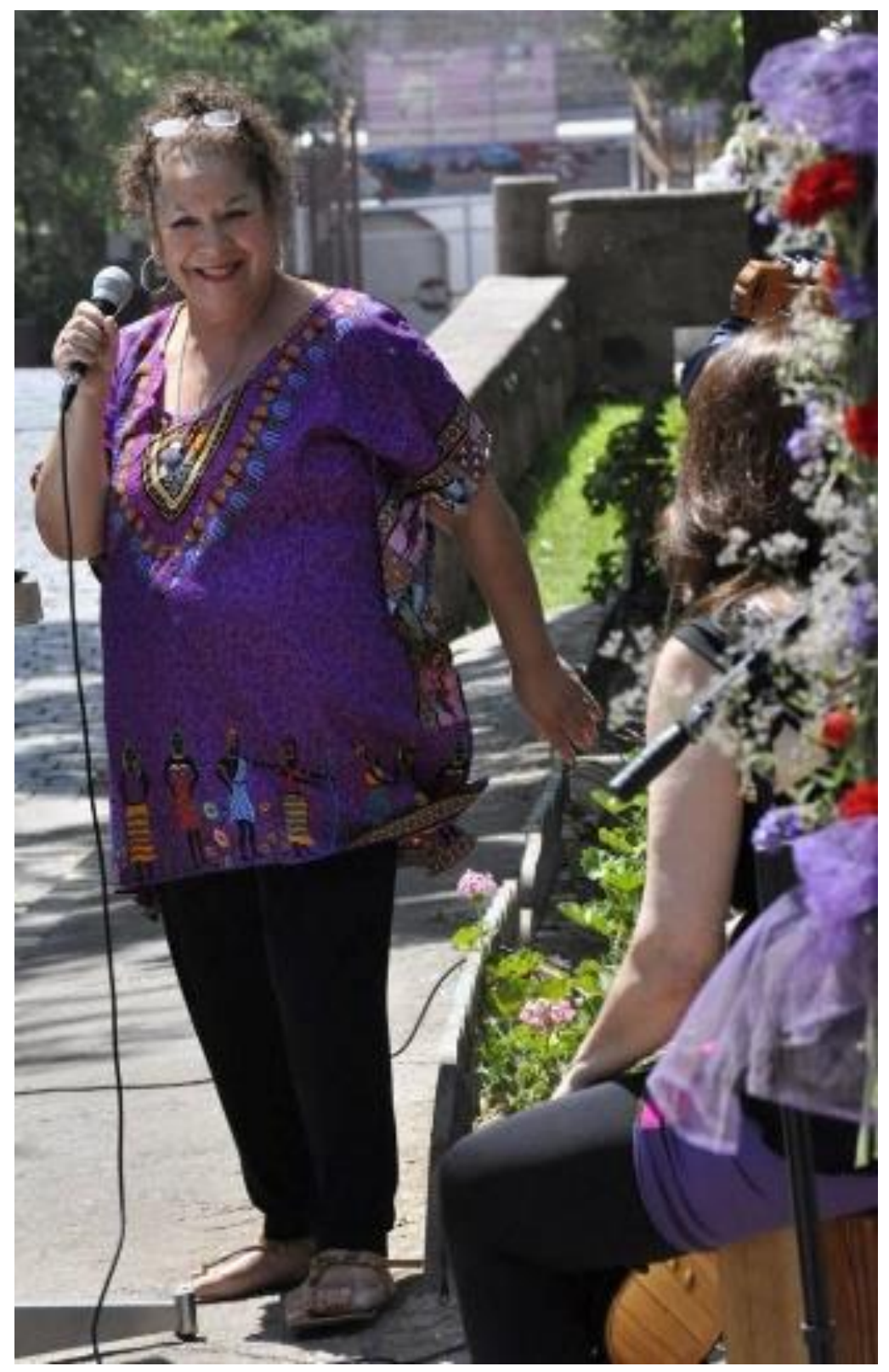

8f. Nora Blanco acompañada por los Cantores que Reflexionan 
Fotografías serie 9a-f. Homenaje organizado por Trío Memorial el 6 de febrero de 2016 Fotografías tomadas por el autor.

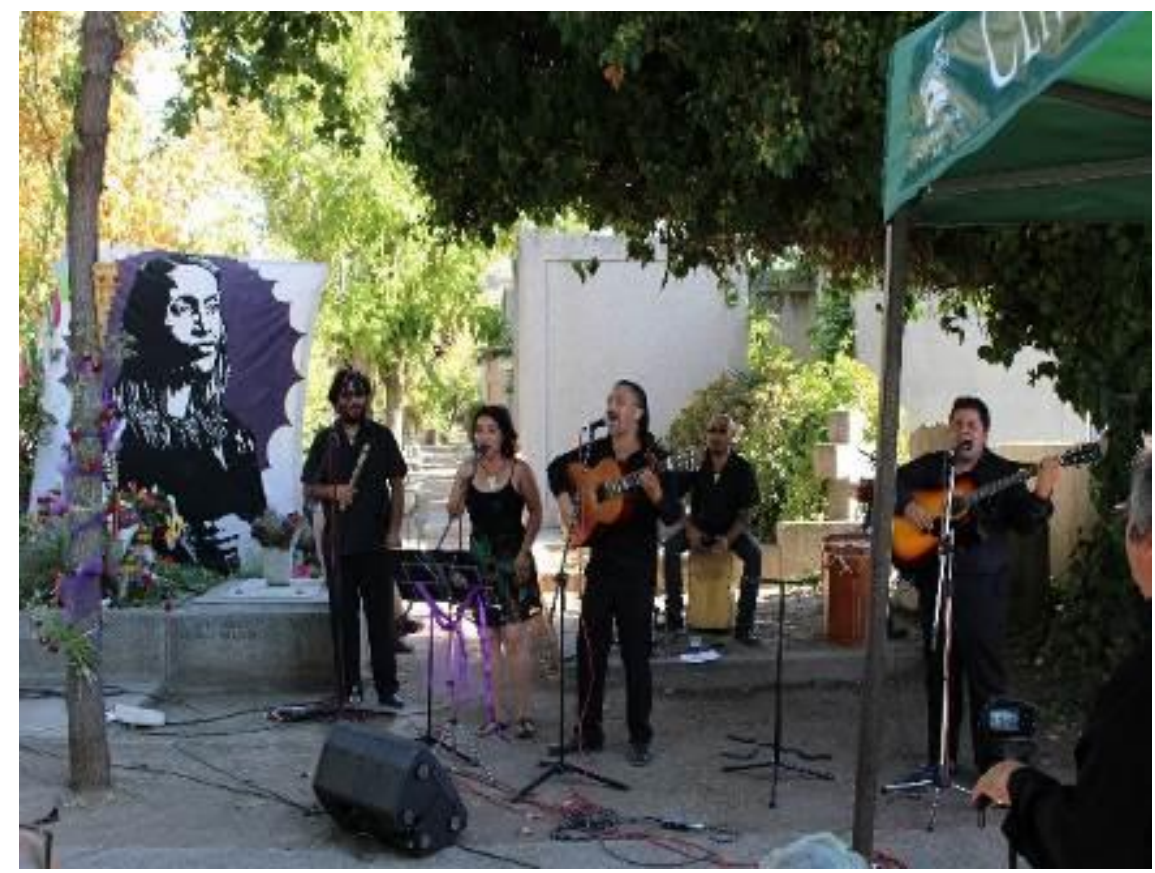

9a. Músicos del Trío Memorial, Nino Vásquez al centro con guitarra

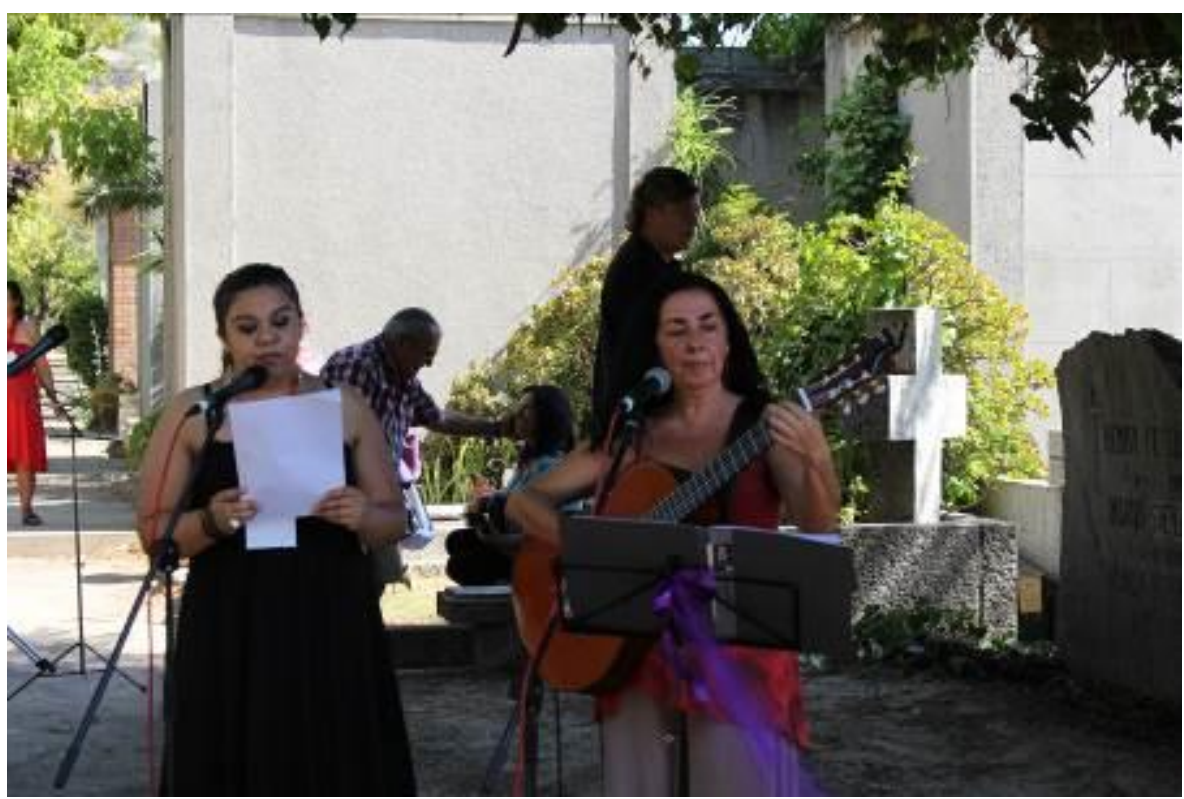

9b. Poeta Carmen Andrea Mantilla y cantora Cecilia Concha Laborde 


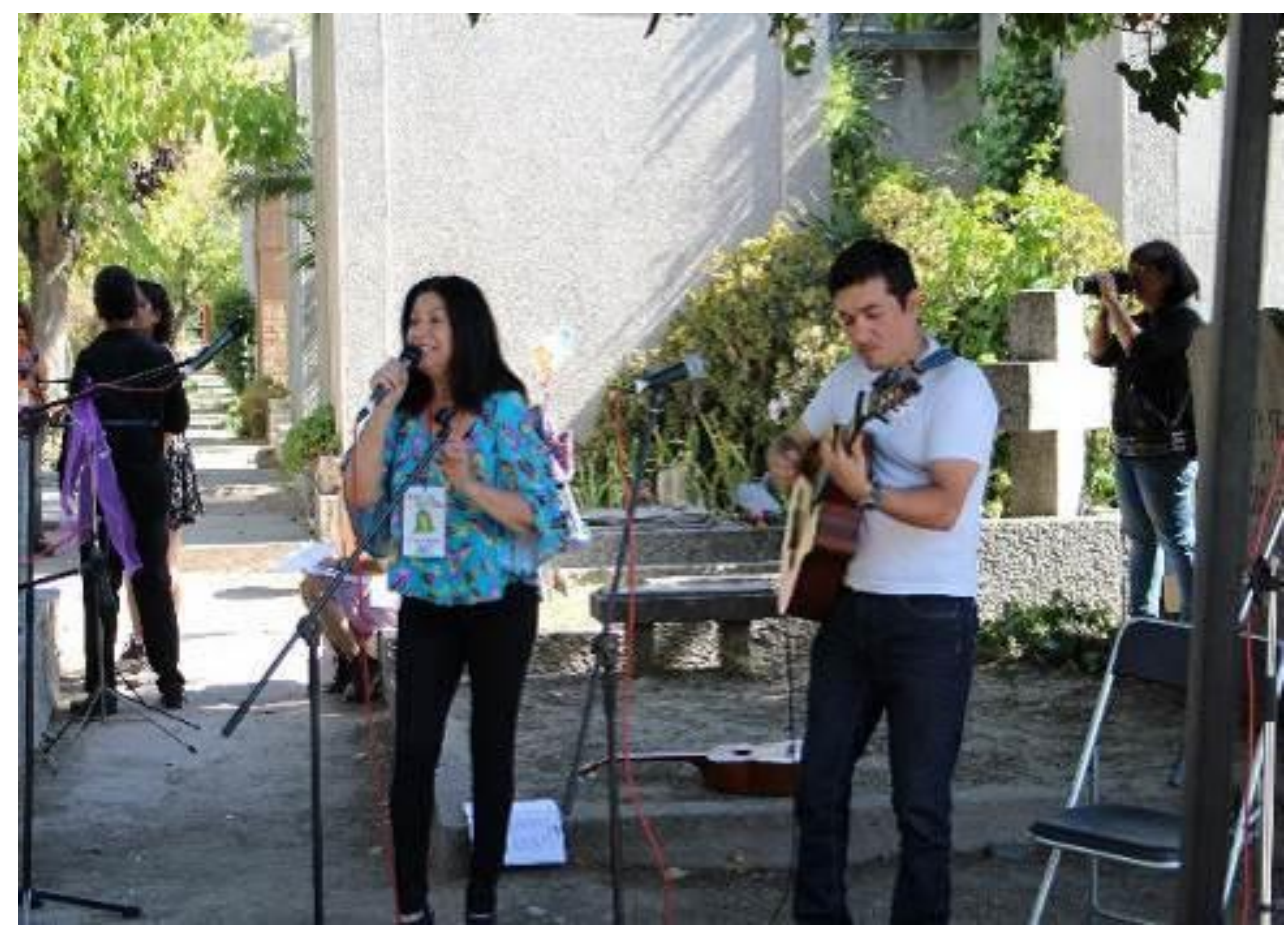

9c. Alexandra Acuña acompañada por su hijo Eloy en guitarra

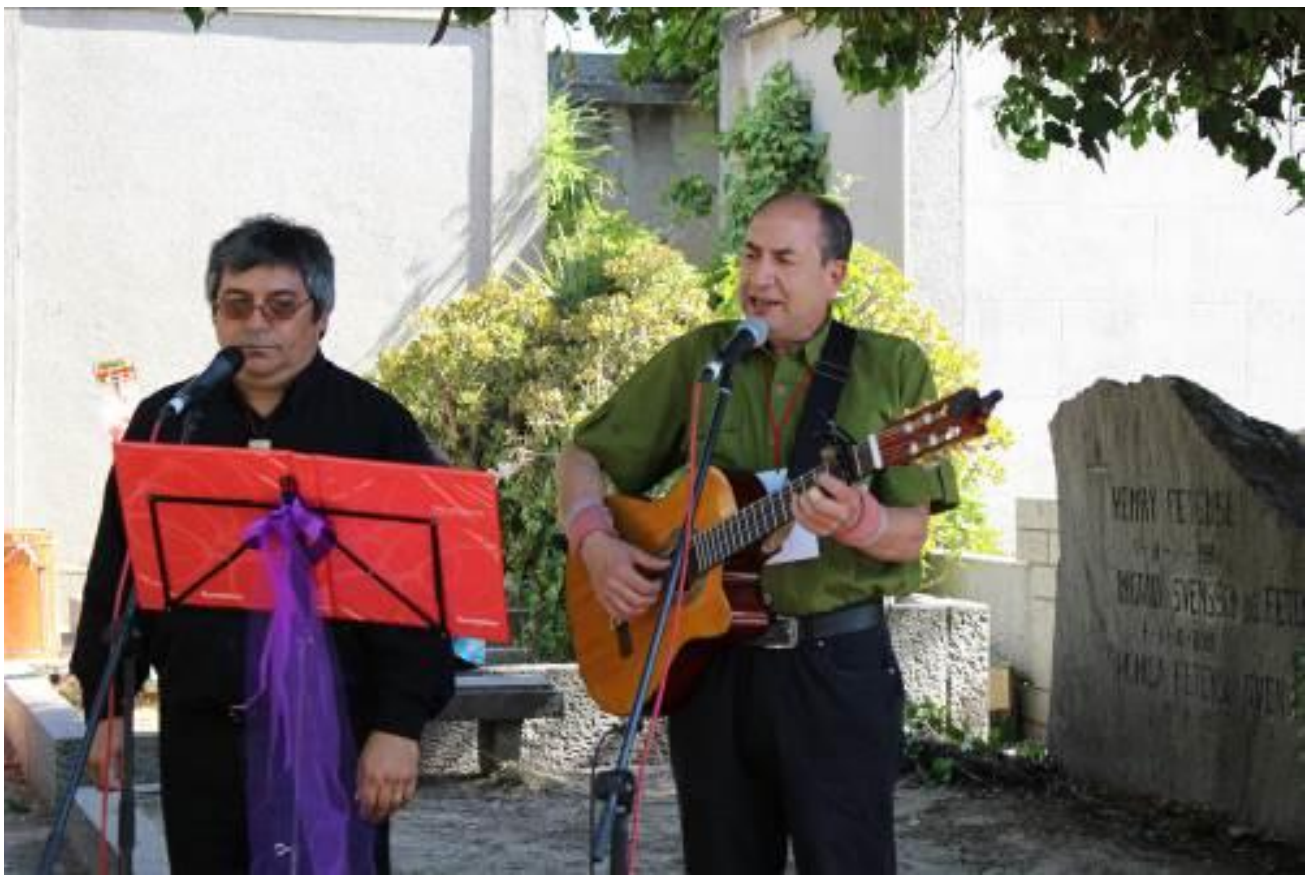

9d. Actor Lucho González (del Trío Memorial) y cantor Pipo Guzmán, declamando y cantando "En defensa de Violeta" de Nicanor Parra/Osvaldo Rodríguez 


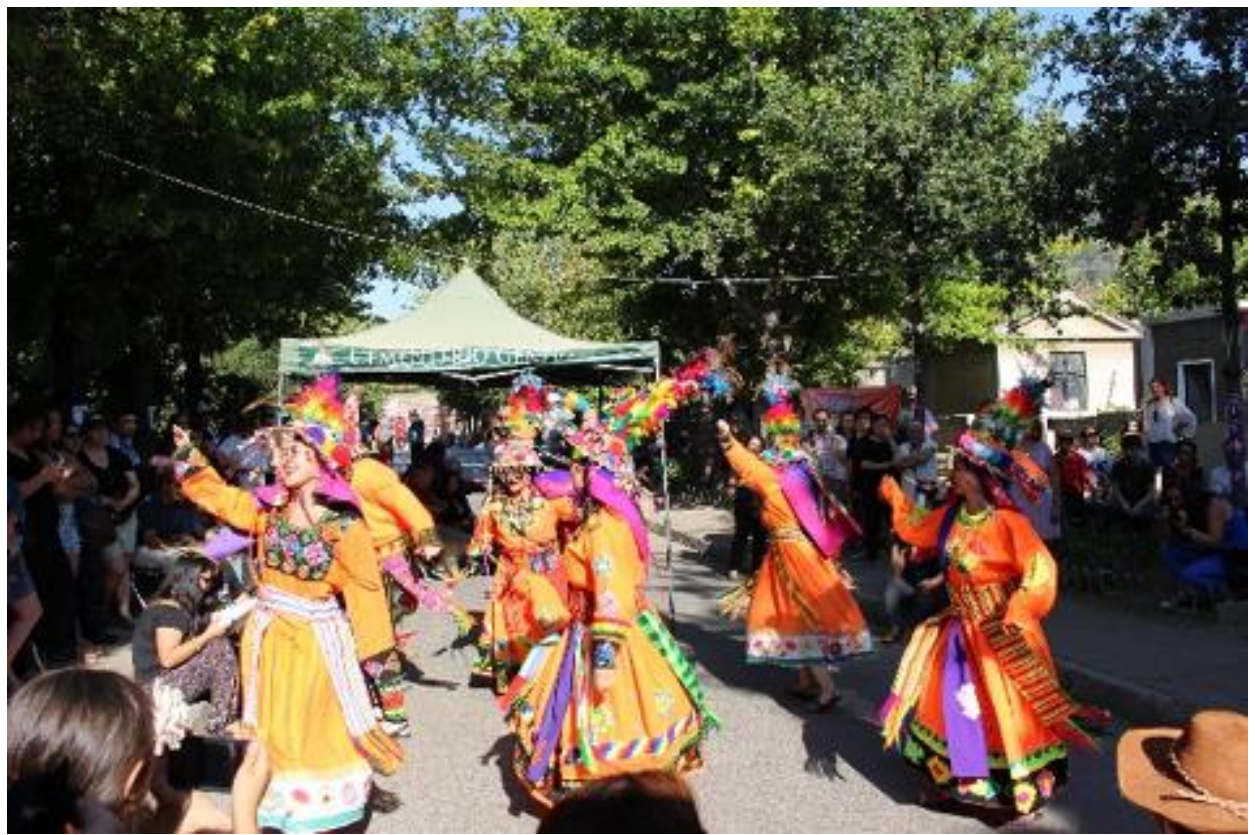

9e. Tinkus, compañía femenina de baile

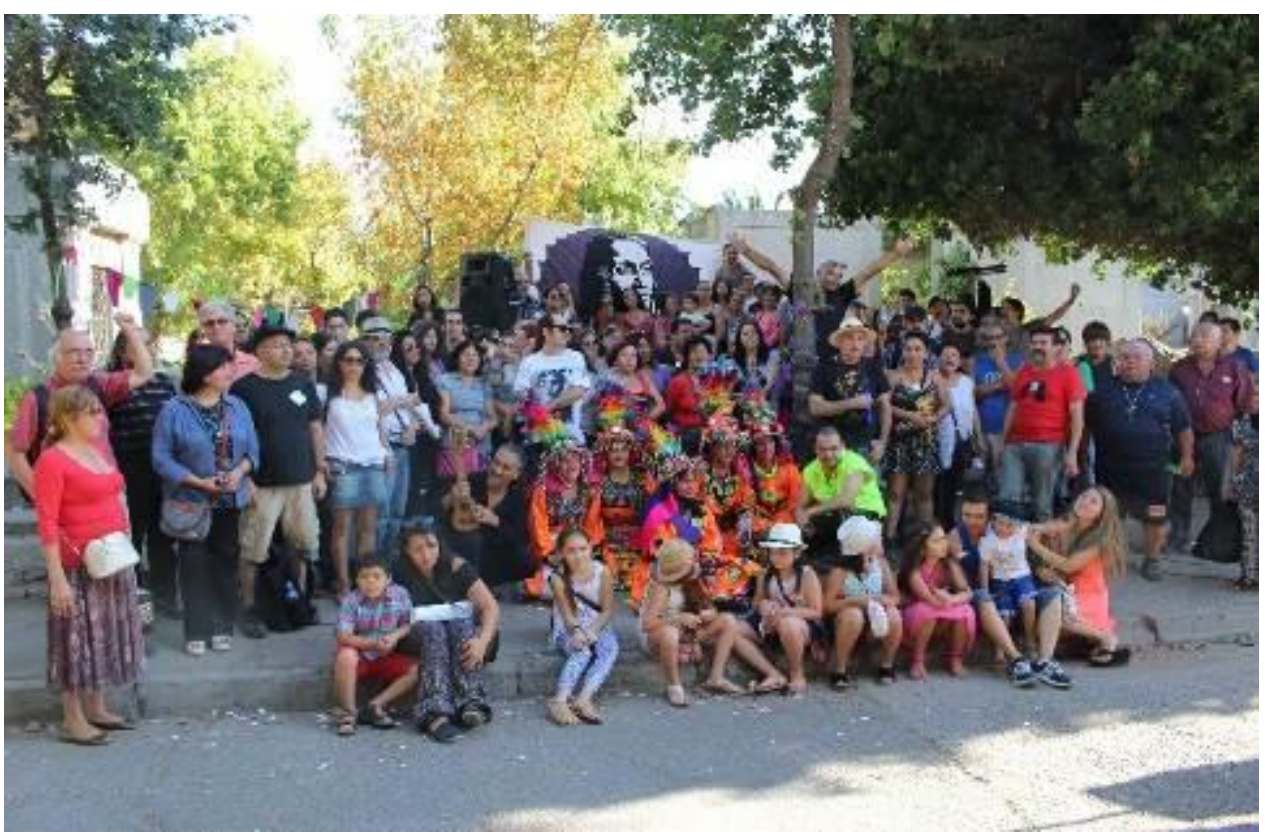

9f. Foto de participantes con miembros del público 
Figura 4. Programa/cancionero para el homenaje del 5 de febrero de 2017

\section{CONVOCAN: \\ CANTO Generat \\ Teio Memorial}

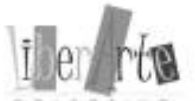

Q19:5

Sertilis

MUJERES DE COLORES

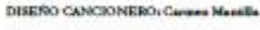

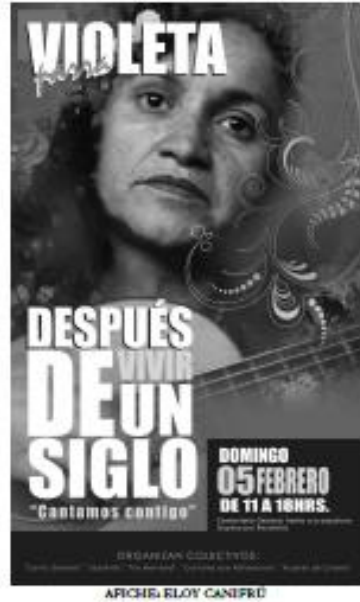

VIOLETA PARRA, HOMENAJE DE LOS ARTISTAS

A 50 AÑOS DE SU "FUGA"

Querida Violeta Parra:

Un 5 de febrero de 1967 te despedías de este mundo, pero te quedabas con nosotros en tu obra inmensa!!

Esta tierra está sembrada de cantores y poetas que han alimentado sus versos con tantos versos tuyos y han descubierto sus melodias rondando tus melodías..

Por eso cada año en esta fecha nos auto convocamos, para compartir canto, y levantar nuestra voz y guitarras

Este domingo 5 de febrero de 2017, al cumplirse 50 años de tu fuga estaremos frente a tu tumba en el Cementerio General, cantando contigo querida cantora mayor!!, despertándote con tus canciones

para que vengas a ayudarnos a despertar conciencias"

jomos 5 colectivos culturales, por primera vez trabajando todos juntos: Janto General" - quienes iniciaron esta conmemoración hace 20 años -

"Trío Memorial", "Colectivo Liberarte", "Mujeres de Colores" y el Colectivo "Cantores que Reflexionan".

Seremos más de 40 músicos y poetas unidos bajo uno de tus más conocidos versos

"Después de Vivir un Siglo... cantamos contigo"

Marcela Shultz y Nora Blanco Bernardino Vásquez Cecilia Concha-Laborde Canto General

Trío Memorial

LiberArte

ndrea Morgado y Leoncio Faúndez Cantores que Reflexionan
Carmen Mantilla y Alexandra Acuña Mujeres de Colorea 